\title{
Molecular identification and in vitro evaluation of probiotic functional properties of some Egyptian lactic acid bacteria and yeasts
}

Al-Shimaa Ibrahim Ahmed', Gihan Mohamed El Moghazy', Tarek Ragab Elsayed ${ }^{2}$, Hanan Abdel Latif Goda ${ }^{2^{*}}$ (D) and Galal Mahmoud Khalafalla²

\begin{abstract}
Background: The health-promoting effects along with global economic importance of consuming food products supplemented with probiotic microorganisms encouraged the researchers to discover new probiotics.

Results: Fourteen lactic acid bacterial isolates were identified as Enterococcus mediterraneensis, Lactobacillus fermentum, and Streptococcus lutetiensis by 165 rRNA gene sequencing, and in vitro characterized for their actual probiotic potential. All E. mediterraneensis isolates were resistant to clindamycin, whereas $L b$. fermentum isolates were resistant to ampicillin, clindamycin, and vancomycin. The $E$. mediterraneensis and $L b$. fermentum isolates displayed high overall digestive survival, ranged from $1.35 \pm 0.06$ to $32.73 \pm 0.84 \%$ and from $2.01 \pm 0.01$ to $23.9 \pm$ $1.85 \%$, respectively. All isolates displayed cell surface hydrophobicity, ranged between $15.44 \pm 6.72$ and $39.79 \pm$ 2.87\%. The strongest auto-aggregation capability, higher than 40\%, was observed for most E. mediterraneensis and Lb. fermentum isolates. The E. mediterraneensis isolates (L2, L12, and L15), Lb. fermentum (L8, L9, and L10), and Strep. lutetiensis (L14) exhibited the greatest co-aggregation with Salmonella typhimurium, Escherichia coli O157:H7, Staphylococcus aureus, and Bacillus cereus. Fifty-seven and fourteen hundredth percent of $E$. mediterraneensis isolates could be considered bacteriocinogenic against E. coli O157:H7, B. cereus, and S. aureus.

Conclusion: This study is the first one to isolate Enterococcus mediterraneensis in Egypt and to characterize it as new species of probiotics globally. According to the results, E. mediterraneensis ( $L 2, L 12$, and $L 15), L b$. fermentum ( $L 8$, L9, and L10), and Strep. lutetiensis (L14) are the most promising in vitro probiotic candidates.
\end{abstract}

Keywords: Enterococcus mediterraneensis, Lactobacillus fermentum, Streptococcus lutetiensis, Probiotics, Functional characteristics

\section{Background}

Increasing the consumers' consciousness of healthpromoting effects of functional foods encouraged both researchers and manufacturers to enhance the production of these food types. The Academy of Nutrition and Dietetics defines functional foods as "whole foods along

\footnotetext{
* Correspondence: hanan.goda@agr.cu.edu.eg

${ }^{2}$ Agricultural Microbiology Department, Faculty of Agriculture, Cairo University, Giza 12613, Egypt

Full list of author information is available at the end of the article
}

with fortified, enriched, or enhanced foods that have a potentially beneficial effect on health when consumed as part of a varied diet on regular basis at effective levels based on significant standards of evidence" [1]. According to this definition, the functional foods could be supplemented with active substances of beneficial biological activity. The food formulations supplemented with probiotics is considered as an important research area for the development of functional food production and marketing. Globally, an increase from 3.3 to 7 billion dollars 
was expected for the market of probiotic dietary supplements throughout the period from 2015 to 2025 [2].

In 2001, the joint Food and Agriculture Organization of the United Nations (FAO) and World Health Organization (WHO) Working Group defined probiotics as "live microorganisms which when administered in adequate amounts confer a health benefit on the host" [3]. The main microbial genera used as probiotics include Lactobacillus, Lactococcus, Enterococcus, Pediococcus, Propionibacterium, Bifidobacterium, Escherichia, Bacillus, Staphylococcus, and some yeast genera, mainly Saccharomyces [4].

For at least the last 15 years, the awareness to use probiotics as an environmentally friendly alternative in food and feed production to improve human and animal health is growing. Several in vitro studies confirmed the health-promoting effects of probiotics comprising antiobesity, anticancer activity, antioxidant activity, inflammatory intestine disease mitigation, food allergy alleviation, improving lactose tolerance, suppression of microbial pathogens, strengthened innate immunity, and serum cholesterol lowering $[5,6]$. Also, probiotic microorganisms are used as an alternative to antibiotics to reduce the drug resistance resulting from mis and overuse of antibiotics for disease treatment in humans and animals [7]. Furthermore, improper drug withdrawal times and addition of unsuitable doses of antibiotics to animal feed for growth promotion led to presence of antibiotic residues in meat and milk. When humans consume these foods, the antibiotic residues will accumulate in the body and may cause numerous side effects as transfer of antibiotic-resistant bacteria to humans, allergy, immunopathological effects, kidney failure, hepatotoxicity, bone marrow toxicity, and reproductive disorders [8]. Generally, the beneficial effects of probiotics are depending on the microbial type, their delivery method, host response, and interaction with other microbes [9].

The probiotic microorganisms should meet the quality assurance criteria for probiotic selection including non-pathogenic and toxigenic activity, gastrointestinal juice tolerance, adherence ability to intestinal epithelial cells, auto- and co-aggregation activities, and antibiotic resistance [10, 11]. In addition to the above, on the commercial scale, the probiotics must retain their vitality and stability during food processing and storage.

From the aforementioned, it is evident the importance of probiotics healthily and economically, which had a great impact for the existence of continuous attempts to discover new probiotics depending on strain selection criteria and their survival during biomass production and storage. Therefore, the main objective of this study was evaluating the potential of some Egyptian lactic acid bacteria and yeast isolates to be probiotic candidates through characterization of their safety and functional properties.

\section{Methods}

\section{Sample collection}

Different samples including animal feed ingredients, dairy products, and meat products were congregated from local markets in Giza Governorate, Egypt to isolate probiotic lactic acid bacteria (LAB) and yeasts. The collected twenty samples of common animal feed ingredients included fish meal (3 samples), corn gluten meal (5 samples), soybean meal (7 samples), and sunflower meal (5 samples). Also, two samples from kareish cheese (local type of fresh soft cheese manufactured from skimmed cow milk), two samples from rayeb milk, one sample from yoghurt, and two samples from processed meat (frankfurter) were screened for the presence of probiotic LAB and yeasts.

\section{Determination and isolation of potential probiotic LAB and yeasts}

The pour plate method was applied to determine and isolate the potential probiotics. de Man, Rogosa, and Sharpe (MRS) agar (Lab M, Neogen Company, UK) at $37{ }^{\circ} \mathrm{C} / 48 \mathrm{~h}$ and rose bengal agar (Lab M, Neogen Company, UK) at $30{ }^{\circ} \mathrm{C} / 48 \mathrm{~h}$ were used to determine total $\mathrm{LAB}$ and yeasts, respectively.

The potential probiotic $\mathrm{LAB}$ and yeasts were isolated using modified MRS agar and rose bengal agar. This modification was represented by lowering $\mathrm{pH}$ to around 2.5 and addition of bile salt with a concentration of $0.3 \%$. The bacterial colonies from modified MRS agar plates were selected randomly for morphological and biochemical characterization. Only pure Gram-positive and catalase-negative isolates were considered as potential probiotic LAB. Other bacterial isolates, with different profile according to Gram staining and catalase test, were considered as not LAB. All bacterial and yeast isolates were preserved at $-20{ }^{\circ} \mathrm{C}$ using MRS broth and rose bengal broth supplemented with $20 \%$ glycerol.

\section{Molecular identification of isolated bacteria and yeasts}

All bacterial and yeast isolates were identified according to $16 \mathrm{~S}$ rRNA and ITS gene sequencing, respectively. All lactic acid bacterial isolates were grown in MRS broth for $24 \mathrm{~h}$ at $37^{\circ} \mathrm{C}$. The other bacterial isolates were cultivated in tryptone glucose yeast extract broth (Lab $\mathrm{M}$, Neogen Company, UK) at $37{ }^{\circ} \mathrm{C} / 24 \mathrm{~h}$. The yeast isolates were grown in rose bengal broth for $24 \mathrm{~h}$ at $30{ }^{\circ} \mathrm{C}$. The cells were harvested by centrifugation at 12,000 g for 5 min. After washing the pellets for three times using $0.85 \% \mathrm{NaCl}$ solution, genomic DNA was extracted using 
GeneJET Genomic DNA purification Kit (ThermoFisher Scientific, Republic of Lithuania). DNA yields and purity were checked using both UV-Vis NanoDrop spectrophotometer (NanoDrop 2000, ThermoFisher Scientific, Germany) and agarose gel electrophoresis (Bio-rad, USA).

To evaluate the genotypic diversity, the BOX-PCR fingerprints of bacteria were generated for all bacterial isolates using BOXA1R primer (CTACGGCAAGGCGACG CTGACG) [12]. The PCR conditions were initial denaturation step at $95{ }^{\circ} \mathrm{C}$ for $12 \mathrm{~min}$, followed by $30 \mathrm{cy}$ cles of $95{ }^{\circ} \mathrm{C}$ for $30 \mathrm{~s}, 55^{\circ} \mathrm{C}$ for $1 \mathrm{~min}$ and $72{ }^{\circ} \mathrm{C}$ for 1 min, and one extension step at $72{ }^{\circ} \mathrm{C}$ for $10 \mathrm{~min}$ at the end of PCR reaction. The PCR tubes were kept at -20 ${ }^{\circ} \mathrm{C}$ until used. Eight microliters of the PCR product were separated by $1.5 \%$ agarose gel electrophoresis in $0.5 \mathrm{X}$ TBE-buffer for $4 \mathrm{~h}(50 \mathrm{~V})$. The BOX-PCR fingerprints patterns were checked and compared visually.

The 16S rRNA gene fragments of 9 LAB isolates were amplified using the universal primers F-27 (5'-AGAGTT TGATCMTGGCTCAG-3') and R-1494 (5'-CTACGG YTACCTTGTTACGAC-3'). For yeast isolates, the internal transcribed spacer (ITS) region was amplified using the universal primers ITS1 $\left(5^{\prime}\right.$-CTTGGTCATT TAGAGGAAGTAA-3') and ITS4 (5'-TCCTCCGCTT ATTGATATGC-3'). The amplification step was performed using Thermal cycler PCR (Bio-rad T100, USA). The PCR conditions for 16S rRNA gene were initial denaturation step at $95{ }^{\circ} \mathrm{C}$ for $12 \mathrm{~min}$, followed by $30 \mathrm{cy}$ cles of $94{ }^{\circ} \mathrm{C}$ for $1 \mathrm{~min}, 56{ }^{\circ} \mathrm{C}$ for $1 \mathrm{~min}$ and $72{ }^{\circ} \mathrm{C}$ for 2 min, and one extension step at $72{ }^{\circ} \mathrm{C}$ for $10 \mathrm{~min}$ at the end of PCR reaction. The PCR conditions for the ITS gene were initial denaturation step at $95{ }^{\circ} \mathrm{C}$ for $12 \mathrm{~min}$, followed by 30 cycles of $95{ }^{\circ} \mathrm{C}$ for $30 \mathrm{~s}, 55{ }^{\circ} \mathrm{C}$ for $30 \mathrm{~s}$ and $72{ }^{\circ} \mathrm{C}$ for $1 \mathrm{~min}$, and one extension step at $72{ }^{\circ} \mathrm{C}$ for $10 \mathrm{~min}$ at the end of PCR reaction. The PCR products were checked via agarose gel electrophoresis then purified using gel extraction kit and sequenced by Macrogen, Inc., Seoul, South Korea using automatic ABI $370 \times 1$ DNA Sequencer (Applied Biosystem, USA). The sequences were analyzed applying BLAST V2.0 software (http://www.ncbi.nlm.nih.gov/BLAST/).

\section{Phylogenetic analysis of bacterial and yeast isolates}

The evolutionary history was inferred using the neighbor-joining method. The tree was computed using the maximum composite likelihood method. Two phylogenetic trees were constructed. The first one involved 30 bacterial nucleotide sequences of which 9 sequences of $16 \mathrm{~S}$ rRNA gene amplified from bacterial isolates, while 21 sequences representing the most similar hits were obtained from the NCBI GeneBank database. The second tree involved 9 yeast sequences of which 4 sequences of ITS regions amplified from yeast isolates, while 5 sequences were from the NCBI GeneBank database. Evolutionary analyses were conducted using MEGA5 software.

\section{Characterization of safety properties Characterization of pathogenicity}

The pathogenicity of isolated probiotics was evaluated through testing the ability of isolates for blood hemolysis. The inoculum from freshly prepared slant culture of $\mathrm{LAB}$ and yeasts was streaked on the blood agar surface with incubation at $37{ }^{\circ} \mathrm{C}$ for $\mathrm{LAB}$ or $30{ }^{\circ} \mathrm{C}$ for yeasts/24-48 h. After the incubation, the cultures were tested for blood hemolysis pattern $(\alpha, \beta$, or $\gamma$ hemolysis). According to the results, all yeast isolates were excluded from this study.

\section{Characterization of antibiotic susceptibility}

The antibiotic resistance of isolated probiotic LAB was examined through determination of minimum inhibitory concentration (MIC) of 9 antibiotics from different antibiotic classes with different antibacterial mode of action (Table 1).

The MIC of selected antibiotics was determined applying the broth dilution method. Each antibiotic was twofold serially diluted, from 128 to $1 \mu \mathrm{g} / \mathrm{mL}$, in MRS broth. The isolated $\mathrm{LAB}$ were grown at $37^{\circ} \mathrm{C}$ for $24 \mathrm{~h}$ in MRS broth supplemented with the given concentrations of antibiotic. After incubation, the calculated MIC was compared with antibiotic breakpoint specified by the European Food Safety Authority (EFSA, 2012) [13] or Clinical and Laboratory Standards Institute (CLSI, 2014 and 2017) $[14,15]$ to categorize the isolates as susceptible or resistant to the tested antibiotic.

\section{Characterization of functional properties}

Gamma hemolytic (nonhemolytic) isolates were assessed for their functional properties. For all characterization tests, the inoculum from $24 \mathrm{~h}$ slant culture of LAB was inoculated in modified MRS broth. The broth cultures grown for $24 \mathrm{~h}$ were centrifuged at $1270 \mathrm{~g}$ for $10 \mathrm{~min}$ to collect the microbial cells, which were washed twice with sterile phosphate buffer solution (PBS) ( $\mathrm{pH}$ 7). The probiotic reference strains Lactobacillus acidophilus ATCC 20552 was used for comparative probiotic characterization. All tests were conducted in three replicates.

\section{Phenol tolerance}

Ability of isolated LAB to survive in the presence of phenol was examined. The bacterial cultures with a count of $10^{7}-10^{8} \mathrm{cfu} / \mathrm{mL}$ were inoculated in MRS broth containing $0.4 \%$ phenol, and incubated at $37{ }^{\circ} \mathrm{C}$ for $24 \mathrm{~h}$. At 0 time and after $24 \mathrm{~h}$ of incubation, the bacterial count was determined employing the pour plate method [16]. 
Table 1 Selected antibiotics to evaluate the antibiotic susceptibility of isolated LAB

\begin{tabular}{llll}
\hline Antibiotic class & Antibiotic & Mode of action & Diluent for stock solution \\
\hline Beta-lactams & Penicillins: ampicillin (AM) & Inhibition of cell wall synthesis & Phosphate buffer \\
Beta-lactams & $\begin{array}{l}\text { Cephalosporins: } \\
\text { 5th generation: ceftolozane (CEF) }\end{array}$ & Inhibition of cell wall synthesis & Water \\
Macrolides & Clindamycin (CLI) & Inhibition of protein synthesis & Water \\
Tetracycline & Tetracycline (TE) & Inhibition of protein synthesis & Water \\
Quinolones & 4th generation: moxifloxacin (MXF) & Inhibition of DNA gyrase & Water \\
Aminoglycosides & Neomycin (NEO) & Inhibition of protein synthesis & Water \\
Sulphonamides & Sulphamethoxazole (SXT) & Inhibition of folic acid metabolism & Water \\
Glycopeptides & Vancomycin (VAN) & Inhibition of cell wall synthesis & Water \\
Synthetic antibiotics & Chloramphenicol (CHL) & Inhibition of protein synthesis & Ethanol 95\% \\
\hline
\end{tabular}

The survival rate was calculated according to the formula:

Survival rate $(\%)=\left(\log \mathrm{cfu} N_{t} / \log \mathrm{cfu} N_{0}\right) \times 100$

As $N_{t}$ and $N_{0}$ represent the surviving count after $24 \mathrm{~h}$ and initial count, respectively.

\section{Survival in a simulated human digestive system}

Influence of human digestion process on the viability of potential probiotic isolates was assessed applying the in vitro gastric and intestinal digestion successively [17]. The gastric digestion was performed using the simulated gastric juice prepared by dissolving $0.13 \mathrm{~g} \mathrm{NaCl}, 0.024 \mathrm{~g}$ $\mathrm{KCl}, 0.64 \mathrm{~g} \mathrm{NaHCO}_{3}$, and $0.3 \mathrm{~g}$ bile salts (Oxford Laboratory, India) in $50 \mathrm{~mL}$ of sterile distilled water. After adjusting the $\mathrm{pH}$ to 2.5, $0.1 \mathrm{~g}$ pepsin (pepsin 1: 3000, Oxford laboratory, India) was dissolved, and the total volume was completed to $100 \mathrm{~mL}$ [18]. The collected cells were resuspended in simulated gastric juice and incubated at $37{ }^{\circ} \mathrm{C} / 2 \mathrm{~h}$ using an orbital shaker at $200 \mathrm{rpm}$. The initial count $\left(C_{0}\right)$ and the surviving count after the gastric digestion were determined by the pour plate method using MRS agar.

The harvested cells from gastric juice were washed in PBS and resuspended in the same volume of simulated intestinal juice formulated by dissolving $0.68 \mathrm{~g}$ monobasic potassium phosphate $\left(\mathrm{KH}_{2} \mathrm{PO}_{4}\right)$ in $25 \mathrm{~mL}$ sterile distilled water. After adjusting the $\mathrm{pH}$ to $6.8,1 \mathrm{~g}$ pancreatin (Ambezim-G, Global Napi Pharmaceuticals, Egypt. Each film-coated tablet contains $5 \mathrm{mg}$ trypsin and $5 \mathrm{mg}$ chymotrypsin which is equivalent to 200,000 proteolytic units) was dissolved, and the total volume was completed to $100 \mathrm{~mL}$ [19]. After incubation at $37^{\circ} \mathrm{C} / 4 \mathrm{~h}$ using an orbital shaker at $200 \mathrm{rpm}$, the count after the intestinal step $\left(C_{i}\right)$ was determined as mentioned before. Overall digestion survival (ODS) was calculated and expressed in percentage according to the formula: ODS $\%=\left(C_{i} / C_{0}\right) \times 100$

\section{Cell surface hydrophobicity assay}

Cell surface hydrophobicity of the isolates was assessed by measuring the microbial adhesion to hydrocarbons [16]. The method was based on the cell affinity to xylene in a two-phase system. The harvested cells were resuspended in $\mathrm{PBS}(\mathrm{pH} 7)$ to an $\mathrm{OD}_{600}$ of $0.6 \pm 0.02$ using the UV/Vis spectrophotometer (Metash UV-800, Shanghai, China) to standardize the count to approximately $10^{7}$ to $10^{8} \mathrm{cfu} / \mathrm{mL}$. Two milliliters of the microbial suspension were mixed with $2 \mathrm{~mL}$ of xylene for 2 min using the vortex mixer. After $30 \mathrm{~min}$ in steady state to allow the separation of two phases, $\mathrm{OD}_{600}$ of the aqueous phase was measured. The percentage of cell surface hydrophobicity $(\mathrm{CSH})$ was calculated according to the following equation:

$\mathrm{CSH} \%=\left[\left(A_{0}-A\right) / A_{0}\right] \times 100$

where $A_{0}$ is the $\mathrm{OD}_{600}$ before mixing, and $A$ is the $\mathrm{OD}_{600}$ after $30 \mathrm{~min}$ of mixing.

\section{Auto-aggregation assay}

Ability of cells for self-binding (auto-aggregation) was evaluated by resuspending the obtained pellet in PBS $(\mathrm{pH} 7)$, followed by adjusting the $\mathrm{OD}_{600}$ at $0.6 \pm 0.02$. During incubation at $37{ }^{\circ} \mathrm{C}$ and without shaking the cell suspension, $\mathrm{OD}_{600}$ was measured at time intervals of 1 , 2,3 , and $24 \mathrm{~h}$ in the upper layer [16]. The percentage of auto-aggregation was calculated applying the following equation: Auto-aggregation $\%=\left[1-\left(A_{t} / A_{0}\right)\right] \times 100$

as $A_{0}$ and $A_{t}$ represent absorbance $\left(\mathrm{OD}_{600 \mathrm{~nm}}\right)$ at 0 time and after selected time of incubation, respectively.

\section{Co-aggregation assay}

The ability of LAB isolates to aggregate with the bacterial pathogens was tested. The selected pathogens comprised Salmonella enterica subsp. enterica serovar Typhimurium ATCC 14028 (Sal. typhimurium), Escherichia coli O157:H7 BCR 594 (E. coli), Staphylococcus aureus subsp. aureus ATCC 25923 (S. aureus) and Bacillus 
cereus BCR 528 (B. cereus). Two milliliters of each lactic acid bacterial suspension prepared in PBS were mixed for $10 \mathrm{~s}$ by a vortex mixer with equal volume of the various suspensions of pathogenic bacteria $\left(10^{7}-10^{8} \mathrm{cfu} /\right.$ $\mathrm{mL}$ ). During incubation of each mixture at $37^{\circ} \mathrm{C} / 24 \mathrm{~h}$, the $\mathrm{OD}_{600 \mathrm{~nm}}$ was measured at time intervals of 2 , 4 , and $24 \mathrm{~h}$ [16]. The co-aggregation ability was determined as follows:

Co-aggregation $\%=\left[\left(A_{\text {mixo }}-A_{\text {mixt }}\right) / A_{\text {mix } 0}\right] \times 100$

as $A_{\text {mix } 0}$ and $A_{\text {mixt }}$ represent absorbance $\left(\mathrm{OD}_{600 \mathrm{~nm}}\right)$ at 0 time and after selected time of incubation, respectively.

\section{Antimicrobial activity assay}

All previous bacterial pathogens were used as indicator microorganisms to evaluate the antibacterial activity of isolated probiotic candidates. To assess the antagonistic activity of isolated LAB, the broth cultures were prepared under both aerobic and anaerobic conditions. After cultivation for $24 \mathrm{~h}$ at $37^{\circ} \mathrm{C}$ under both conditions, the cells were removed from the cultures by centrifugation at 1270 $\mathrm{g}$ for $15 \mathrm{~min}$, followed by filtration of the supernatant through a cellulose acetate membrane filter with a pore size of $0.22 \mu \mathrm{m}$. The filtrate from broth cultures prepared aerobically was considered as crude extract that could contain $\mathrm{H}_{2} \mathrm{O}_{2}$, organic acids, and bacteriocins (Extract 1). On the other hand, the filtrate from broth cultures prepared anaerobically was considered as crude extract that could contain organic acids and bacteriocins only (Extract 2). To eliminate the inhibitory effect of organic acids in Extract 2, the cell-free supernatant was neutralized with 1 $\mathrm{M} \mathrm{NaOH}$. The resulting is referred to as a crude bacteriocin, if produced (Extract 3). The antibacterial activity of all extracts was screened applying the well-diffusion assay (cup-plate method) [20], in which $200 \mu \mathrm{L}$ of the extract was added in a well of $10 \mathrm{~mm}$ diameter made into the plate containing agar medium inoculated with the test microorganism. The plates were incubated at $37{ }^{\circ} \mathrm{C}$ for 24 h. Growth inhibition appeared as a measurable clear zone around the disc.

\section{Statistical analysis}

Data were expressed as mean \pm standard deviation (SD). The differences between the isolates were statistically evaluated by one-way analysis of variance (ANOVA) followed by Tukey's multiple comparison test using Graph Pad Prism program 7.0. $P<0.05$ was considered significant.

\section{Results}

Determination and isolation of potential probiotic LAB and yeasts

Neither LAB nor yeasts were isolated from all collected animal feed ingredients. On the other hand, LAB, yeasts and their corresponding acid-bile salt-tolerant cells were determined and isolated from tested food samples.

The results revealed infrequent presence of acid-bile salt-tolerant bacteria in food samples. The highest percentage was recorded in yoghurt (3.0\%), followed by rayeb milk (0.02-0.03\%). The lowest incidence was in kareish cheese and frankfurter with a percentage of $2.0 \times$ $10^{-6}$ to $4.0 \times 10^{-5} \%$ and $3.0 \times 10^{-5}$ to $3.0 \times 10^{-4} \%$, respectively.

The acid-bile salt-tolerant yeasts were determined only in kareish cheese in the range of $3.0 \times 10^{-5}$ to $2.0 \times$ $10^{-4} \%$.

A total of 16 and 4 isolates, characterized as acid and bile salt-tolerant bacteria (designated as L1-L16) and yeasts (designated as $\mathrm{Y} 1-\mathrm{Y} 4$ ), respectively, were selected randomly. The bacterial isolates included 2, 4, and 9 isolates from kareish cheese, rayeb milk, and frankfurter samples, correspondingly. Also, 1 isolate was obtained from the yoghurt sample. Gram staining and catalase test categorized the isolates into 3 classes: (i) $\mathrm{G}^{+}$and catalase negative cocci (9 isolates), (ii) $\mathrm{G}^{+}$and catalase negative rods (5 isolates), and (iii) $\mathrm{G}^{+}$and catalase positive sporulated rods (2 isolates).

Morphologically, the 4 yeast isolates, obtained from kareish cheese, were oval-shaped cells.

\section{Bacterial fingerprints and genotypic diversity}

BOX-PCR fingerprints were generated for all acidbile salt-tolerant bacterial isolates (16 isolates) to show their genotypic diversity. Three major genotypes with multiple isolates were detected in addition to 5 unique fingerprint profiles each with only one single pattern (Fig. 1). Identical fingerprint profiles were recorded among the isolates (L13 and L14) and between the isolates (L4, L5, L8, L9, and L10) and (L3, L11, L12, and L15). At least one representative isolate

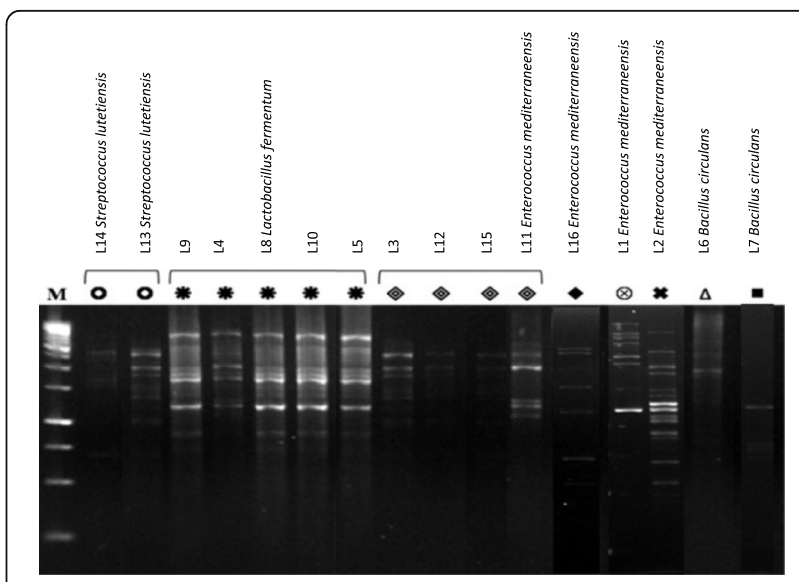

Fig. 1 BOX-PCR fingerprints of 16 bacterial isolates. Fingerprint profiles labeled with the same symbol are identical. M, 1 Kb ladder 
from each fingerprint profile was identified based on the sequence of $16 \mathrm{~S}$ rRNA gene.

\section{S rRNA-based identification and phylogenetic analysis of bacterial isolates}

Nine bacterial isolates, representing different BOXPCR fingerprint profiles, were identified based on the sequencing of $16 \mathrm{~S}$ rRNA gene. The phylogenetic analysis with closest hits obtained from the NCBI GeneBank is presented in Fig. 2. The $16 \mathrm{~S}$ rRNA sequence revealed that the isolates L1, L2, L16, and L11 showed 99\% similarity to Enterococcus mediterraneensis (E. mediterraneensis), the isolates L6 and L7 were 99 and 100\% similar to Bacillus circulans (B. circulans) respectively, while L8 showed 99\% similarity to Lactobacillus fermentum ( $L b$. fermentum). The isolates
L13 and L14 showed 99\% similarity to Streptococcus lutetiensis (Strep. lutetiensis).

\section{ITS-based identification and phylogenetic analysis of yeast isolates}

The phylogenetic analysis of yeast isolates based on the sequencing of the ITS region is presented in Fig. 3. All yeast isolates were identified as Clavispora lusitaniae with similarity ranged from 98.6 to $99.7 \%$ (Table 2).

The sequences of LAB and yeast isolates were deposited on the GeneBank under accession numbers presented in Table 2.

\section{Characterization of safety properties Characterization of pathogenicity}

The blood hemolysis test was conducted to characterize the pathogenicity of catalase-negative bacteria (14

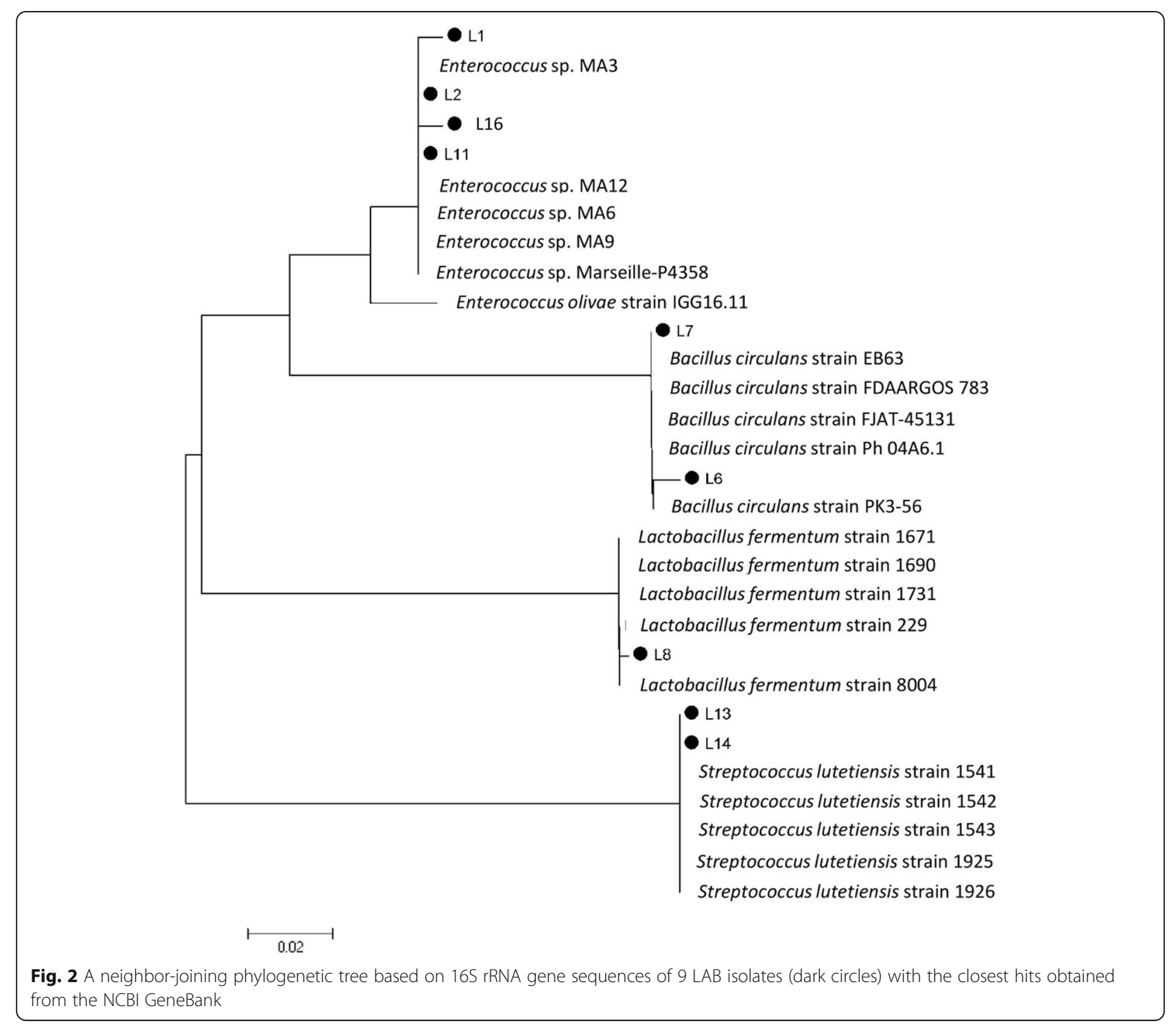




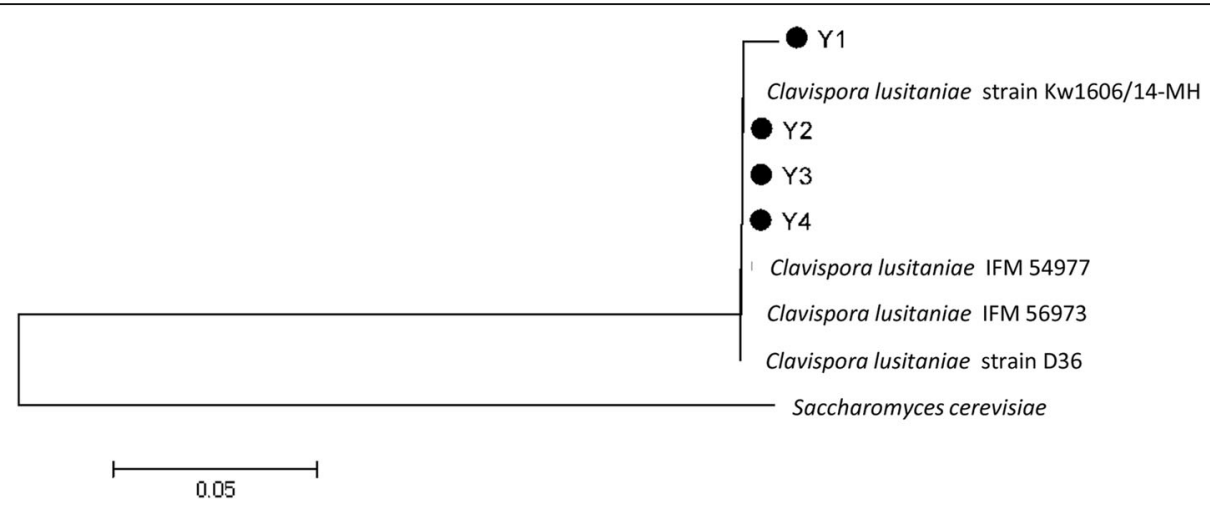

Fig. 3 A neighbor-joining phylogenetic tree based on ITS gene sequences of 4 yeast isolates (dark circles) with the closest hits obtained from the NCBI GeneBank

isolates) and all yeast isolates. The results confirmed that the colonies of all tested bacterial isolates were not surrounded by clear or greenish zone on blood agar indicating that these isolates are gamma hemolytic or nonhemolytic bacteria. Conversely, the 4 yeast isolates were characterized as alpha hemolytics.

The gamma hemolytic lactic acid bacteria were tested to define their antibiotic susceptibility profile and characterized functionally in vitro to evaluate their actual probiotic potential.

\section{Characterization of antibiotic susceptibility}

The antibiotic susceptibility of all 14 LAB isolates was assessed through determination of minimum inhibitory concentration (MIC) of 9 antibiotics (Table 3). According to the antibiotic breakpoints reported by EFSA (2012) and CLSI (2014 and 2017), the antibiotic resistance of putative probiotic LAB was specified. All E. mediterraneensis isolates were sensitive to neomycin and vancomycin and resistant to clindamycin. Alternatively, $14.29 \%$ were resistant to ampicillin and ceftolozane, $42.86 \%$ to tetracycline and chloramphenicol, and $57.14 \%$ to moxifloxacin and sulphamethoxazole. All Lb. fermentum isolates were sensitive to ceftolozane, neomycin, and sulphamethoxazole; and resistant to ampicillin, clindamycin, and vancomycin. On the other hand, $80 \%$ were resistant to chloramphenicol and $40 \%$ to tetracycline and moxifloxacin. The two isolates of Strep. lutetiensis (L13 and L14) were resistant to ampicillin, clindamycin, tetracycline, moxifloxacin, sulphamethoxazole, and vancomycin, and completely susceptible to ceftolozane, neomycin, and chloramphenicol.

\section{Characterization of functional properties Phenol tolerance}

In the presence of $0.4 \%$ phenol, the survival rate of $E$. mediterraneensis and $L b$. fermentum isolates ranged from $64.9 \pm 1.41$ to $102.97 \pm 0.67 \%$ and from $52.59 \pm$

Table 2 Accession numbers and closest hits of $L A B$ and yeast isolates

\begin{tabular}{|c|c|c|c|c|}
\hline Isolate no. & Source of isolation & Closest hit & Gene identity (\%) & GenBank accession number \\
\hline L1 & Rayeb milk & Enterococcus mediterraneensis MA3 & 99 & MT860218 \\
\hline L2 & Rayeb milk & Enterococcus mediterraneensis MA12 & 99 & MT860219 \\
\hline L16 & Kareish cheese & Enterococcus mediterraneensis MA12 & 99 & MT860213 \\
\hline L11 & Frankfurter & Enterococcus mediterraneensis MA12 & 99 & MT860215 \\
\hline L6 & Frankfurter & Bacillus circulans strain PK3-56 & 99 & MT860220 \\
\hline L7 & Frankfurter & Bacillus circulans strain EB63 & 100 & MT860221 \\
\hline L8 & Frankfurter & Lactobacillus fermentum strain 8004 & 99 & MT860214 \\
\hline L13 & Frankfurter & Streptococcus lutetiensis strain 1541 & 99 & MT860216 \\
\hline L14 & Frankfurter & Streptococcus lutetiensis strain 1541 & 99 & MT860217 \\
\hline Y1 & Kareish cheese & Clavispora lusitaniae IFM 549787 & 98.6 & MT880128 \\
\hline Y2 & Kareish cheese & Clavispora lusitaniae IFM 56973 & 99.7 & MT880130 \\
\hline Y3 & Kareish cheese & Clavispora lusitaniae IFM 56973 & 99.45 & MT880132 \\
\hline Y4 & Kareish cheese & Clavispora lusitaniae IFM 56973 & 99.17 & MT880131 \\
\hline
\end{tabular}


Table 3 Minimum inhibitory concentration $(\mu \mathrm{g} / \mathrm{mL})$ of 9 antibiotics against isolated $L A B$

\begin{tabular}{|c|c|c|c|c|c|c|c|c|c|c|}
\hline \multirow{2}{*}{$\begin{array}{l}\text { Isolate } \\
\text { no. }\end{array}$} & \multirow[t]{2}{*}{ Isolate identification } & \multicolumn{9}{|c|}{ MIC $(\mu \mathrm{g} / \mathrm{mL})$} \\
\hline & & $\overline{A M^{2}}$ & $\mathrm{CEF}^{3}$ & $\mathrm{CLI}^{4}$ & $\mathrm{TE}^{5}$ & $\mathrm{MXF}^{6}$ & $\mathrm{NEO}^{7}$ & $\mathrm{SXT}^{8}$ & VAN $^{9}$ & $\mathrm{CHL}^{10}$ \\
\hline$\overline{\mathrm{PRS}^{1}}$ & Lb. acidophilus ATCC 20552 & $16 R^{11}$ & $16 S^{12}$ & $2 \mathrm{R}$ & $2 S$ & $4 R$ & $32 R$ & $4 \mathrm{R}$ & $2 R$ & $64 R$ \\
\hline L1 & E. mediterraneensis & $4 S$ & $2 \mathrm{~S}$ & $8 R$ & $4 S$ & $21^{13}$ & $2 S$ & $2 S$ & $2 \mathrm{~S}$ & $4 S$ \\
\hline L2 & & $2 \mathrm{~S}$ & $2 S$ & $2 \mathrm{R}$ & $4 S$ & 21 & $2 S$ & $4 \mathrm{R}$ & $4 \mathrm{~S}$ & $8 S$ \\
\hline L3 & & $2 \mathrm{~S}$ & $2 S$ & $2 \mathrm{R}$ & $2 S$ & 21 & $2 S$ & $4 \mathrm{R}$ & $2 S$ & $128 \mathrm{R}$ \\
\hline L11 & & $8 \mathrm{~S}$ & $64 \mathrm{R}$ & $2 \mathrm{R}$ & $64 \mathrm{R}$ & $8 \mathrm{R}$ & 85 & $4 \mathrm{R}$ & $2 S$ & $32 \mathrm{R}$ \\
\hline L12 & & $2 \mathrm{~S}$ & $2 S$ & $2 \mathrm{R}$ & $32 \mathrm{R}$ & $8 R$ & $2 S$ & $2 S$ & $2 S$ & 161 \\
\hline L15 & & $8 \mathrm{~S}$ & $8 S$ & $2 \mathrm{R}$ & 81 & $4 \mathrm{R}$ & 85 & $2 S$ & $4 S$ & $2 S$ \\
\hline L16 & & $32 \mathrm{R}$ & 325 & $2 \mathrm{R}$ & $32 R$ & $4 \mathrm{R}$ & $4 S$ & $4 \mathrm{R}$ & $2 S$ & $32 \mathrm{R}$ \\
\hline$\llcorner 4$ & Lb. fermentum & $2 \mathrm{R}$ & $4 \mathrm{~S}$ & $2 \mathrm{R}$ & $2 S$ & $2 S$ & 85 & $2 S$ & $8 \mathrm{R}$ & $2 S$ \\
\hline L5 & & $2 \mathrm{R}$ & $2 S$ & $2 \mathrm{R}$ & $4 S$ & $2 S$ & $2 S$ & $2 S$ & $8 \mathrm{R}$ & $4 \mathrm{R}$ \\
\hline L8 & & $4 \mathrm{R}$ & $2 S$ & $2 \mathrm{R}$ & $8 \mathrm{R}$ & $4 \mathrm{R}$ & $2 S$ & $2 S$ & $2 \mathrm{R}$ & $4 \mathrm{R}$ \\
\hline L9 & & $8 R$ & $2 S$ & $2 \mathrm{R}$ & $2 S$ & $2 S$ & 85 & $2 S$ & $2 R$ & $8 \mathrm{R}$ \\
\hline L10 & & $8 R$ & $32 S$ & $2 \mathrm{R}$ & $32 \mathrm{R}$ & $8 R$ & 85 & $2 S$ & $8 \mathrm{R}$ & $32 \mathrm{R}$ \\
\hline L13 & Strep. Iutetiensis & $4 \mathrm{R}$ & $2 S$ & $4 \mathrm{R}$ & $16 \mathrm{R}$ & $8 R$ & 325 & $16 \mathrm{R}$ & $8 \mathrm{R}$ & $2 S$ \\
\hline L14 & & $4 \mathrm{R}$ & $2 S$ & $4 \mathrm{R}$ & $16 \mathrm{R}$ & $8 \mathrm{R}$ & $32 S$ & $16 \mathrm{R}$ & $8 \mathrm{R}$ & $2 S$ \\
\hline
\end{tabular}

1: probiotic reference strain. 2: ampicillin. 3: ceftolozane. 4: clindamycin. 5: tetracycline. 6: moxifloxacin. 7: neomycin. 8: sulphamethoxazole. 9: vancomycin. 10: chloramphenicol. 11: resistant. 12: sensitive. 13: intermediate resistant

1.26 to $99.34 \pm 0.93 \%$, correspondingly (Table 4 ). The two isolates of Strep. lutetiensis had phenol tolerance higher than $80 \%$.

From the total isolates, $28.57 \%$ had the ability to grow significantly better than the reference strain with a survival rate ranging from $99.34 \pm 0.93$ to $102.97 \pm 0.67 \%$. These isolates were E. mediterraneensis (L1, L2, and L16), and Lb. fermentum (L9). The isolates L3, L4, and L5 showed the least tolerance to phenol with a survival rate ranged from $52.59 \pm 1.26$ to $78.65 \pm 1.48 \%$.

It was observed that the phenol, with a concentration of $0.4 \%$, has rather stimulating effect on the growth of one isolate of E. mediterraneensis (L16 isolated from kareish cheese) as the survival rate reached more than $100 \%$.

\section{Survival in a simulated human digestive system}

The results in Table 5 elucidated that $57.14 \%$ of E. mediterraneensis isolates displayed ODS ranged between $11.43 \pm 1.29$ and $32.73 \pm 0.84 \%$, whereas $80 \%$ of $\mathrm{Lb}$. fermentum isolates had ODS in a range from $11.38 \pm 0.33$ to $23.9 \pm 1.85 \%$.

It was revealed that the superior survival rates of 32.73 \pm 0.84 and $23.9 \pm 1.85 \%$, through gastric and intestinal transit, appeared with E. mediterraneensis (L2) and $L b$. fermentum (L8), respectively. The isolates of $E$.

Table 4 Phenol tolerance of isolated $L A B$

\begin{tabular}{|c|c|c|c|c|c|}
\hline Isolate no. & Isolate identification & Survival rate (\%) & Isolate no. & Isolate identification & Survival rate (\%) \\
\hline$\overline{\mathrm{PRS}^{1}}$ & Lb. acidophilus ATCC 20552 & $99.25 \pm 0.88$ & L4 & Lb. fermentum & $78.65 \pm 1.48$ \\
\hline L1 & E. mediterraneensis & $99.52 \pm 0.67^{*}$ & L5 & & $52.59 \pm 1.26$ \\
\hline L2 & & $99.45 \pm 0.77^{*}$ & L8 & & $85.46 \pm 1.14^{*}$ \\
\hline L3 & & $64.9 \pm 1.41$ & L9 & & $99.34 \pm 0.93^{*}$ \\
\hline L11 & & $89.51 \pm 1.54^{*}$ & L10 & & $84.77 \pm 0.13^{*}$ \\
\hline L12 & & $87.79 \pm 0.77^{*}$ & $\mathrm{~L} 13$ & Strep. lutetiensis & $80.34 \pm 1.59$ \\
\hline L15 & & $87.67 \pm 1.14^{*}$ & L14 & & $98.83 \pm 0.37^{*}$ \\
\hline L16 & & $102.97 \pm 0.67^{*}$ & & & \\
\hline
\end{tabular}


Table 5 Overall digestion survival (ODS) of potential probiotic LAB

\begin{tabular}{|c|c|c|c|c|c|}
\hline Isolate no. & Isolate identification & ODS (\%) & Isolate no. & Isolate identification & ODS (\%) \\
\hline$\overline{\mathrm{PRS}^{1}}$ & Lb. acidophilus ATCC 20552 & $4.68 \pm 0.74$ & L4 & Lb. fermentum & $11.99 \pm 1.33^{*}$ \\
\hline L1 & E. mediterraneensis & $2.09 \pm 0.3$ & L5 & & $14.77 \pm 0.32^{*}$ \\
\hline L2 & & $32.73 \pm 0.84^{*}$ & L8 & & $23.9 \pm 1.85^{*}$ \\
\hline L3 & & $11.43 \pm 1.29^{*}$ & L9 & & $2.01 \pm 0.01$ \\
\hline L11 & & $15.39 \pm 1.56^{*}$ & L10 & & $11.38 \pm 0.33^{*}$ \\
\hline L12 & & $13.35 \pm 0.35^{*}$ & L13 & Strep. Iutetiensis & $11.02 \pm 0.43^{*}$ \\
\hline L15 & & $1.56 \pm 0.16$ & L14 & & $9.42 \pm 0.13$ \\
\hline L16 & & $1.35 \pm 0.06$ & & & \\
\hline
\end{tabular}

1: probiotic reference strain. Data are expressed as mean \pm SD (standard deviation). ${ }^{*} P$ values were $<0.05$.

mediterraneensis (L3, L11, and L12), Lb. fermentum (L4, L5, and L10), and Strep. lutetiensis (L13) displayed lower survival significantly.

\section{Cell surface hydrophobicity assay}

The results shown in Table 6 indicated that all LAB isolates revealed a different degree of hydrophobicity in xylene which ranged between $15.44 \pm 6.72$ and $39.79 \pm$ 2.87\%. The isolates of E. mediterraneensis (L3), Lb. fermentum (L5), and Strep. lutetiensis (L13) had strong hydrophobicity represented by $37.87 \pm 9.71 \%, 38.88 \pm$ $8.07 \%$, and $39.79 \pm 2.87 \%$, correspondingly comparing to the reference strain $(26.44 \pm 2.31 \%)$.

1: probiotic reference strain. Data are expressed as mean $\pm \mathrm{SD}$ (standard deviation). ${ }^{*} P$ values were ${ }^{<} 0.05$.

\section{Auto-aggregation assay}

Generally, the results confirmed increasing the capability of all LAB isolates to aggregate with extending the incubation time (Table 7). Within the same time, there are significant differences between some isolates for their auto-aggregation capability. The strongest autoaggregation ability, higher than $40 \%$ after 24 h, was observed for all E. mediterraneensis isolates except L3, and all $L b$. fermentum isolates except L4. The highest autoaggregation percentages of $64.71 \pm 0.95,63.61 \pm 2.65$, and $61.74 \pm 1.8 \%$ were recorded for $E$. mediterraneensis
(L11), Lb. fermentum (L10), and Strep. lutetiensis (L14), respectively.

\section{Co-aggregation assay}

The co-aggregation ability of LAB with bacterial pathogens Sal. enterica subsp. enterica serovar Typhimurium ATCC 14028, E. coli O157:H7 BCR 594, S. aureus subsp. aureus ATCC 25923 and B. cereus BCR 528 were evaluated (Tables 8 and 9). Similar to auto-aggregation, the co-aggregation ability with all selected bacterial pathogens was directly proportional with the incubation time. Also, it was observed that there are significant differences between some isolates for their co-aggregation capability during the same incubation time.

Obviously, the results of Table 8 indicated that the coaggregation capability of $E$. mediterraneensis (L12), Lb. fermentum (L10), and Strep. lutetiensis (L13 and L14) with Sal. typhimurium has not changed for $20 \mathrm{~h}$. After $24 \mathrm{~h}$, the co-aggregation ability of $E$. mediterraneensis and $\mathrm{Lb}$. fermentum with Sal. typhimurium ranged from $16.39 \pm 7.91$ to $62.95 \pm 1.35 \%$ and from $20.04 \pm 3.72$ to $49.45 \pm 1.25 \%$, respectively. The strongest coaggregation of $62.95 \pm 1.35,49.45 \pm 1.25$, and $45.16 \pm$ $0.63 \%$ were recorded for $E$. mediterraneensis (L2), $L b$. fermentum (L8), and Strep. lutetiensis (L14), correspondingly.

Table 6 Cell surface hydrophobicity (CSH) of isolated LAB

\begin{tabular}{|c|c|c|c|c|c|}
\hline Isolate no. & Isolate identification & CSH (\%) & Isolate no. & Isolate identification & CSH (\%) \\
\hline$\overline{\mathrm{PRS}^{1}}$ & Lb. acidophilus ATCC 20552 & $26.44 \pm 2.31$ & L4 & Lb. fermentum & $36.15 \pm 6.0$ \\
\hline L1 & E. mediterraneensis & $23.24 \pm 6.63$ & L5 & & $38.88 \pm 8.07^{*}$ \\
\hline L2 & & $15.44 \pm 6.72$ & L8 & & $25.40 \pm 2.4$ \\
\hline L3 & & $37.87 \pm 9.71^{*}$ & L9 & & $20.87 \pm 4.93$ \\
\hline L11 & & $23.46 \pm 3.19$ & L10 & & $24.29 \pm 1.53$ \\
\hline L12 & & $24.22 \pm 2.33$ & L13 & Strep. lutetiensis & $39.79 \pm 2.87^{*}$ \\
\hline L15 & & $23.04 \pm 6.22$ & L14 & & $25.95 \pm 3.01$ \\
\hline L16 & & $19.33 \pm 2.93$ & & & \\
\hline
\end{tabular}


Table 7 Auto-aggregation capability of potential probiotic LAB

\begin{tabular}{|c|c|c|c|c|c|}
\hline \multirow{2}{*}{$\begin{array}{l}\text { Isolate } \\
\text { no. }\end{array}$} & \multirow[t]{2}{*}{ Isolate identification } & \multicolumn{4}{|c|}{ Auto-aggregation (\%) } \\
\hline & & $1 \mathrm{~h}$ & $2 \mathrm{~h}$ & $3 \mathrm{~h}$ & $24 \mathrm{~h}$ \\
\hline$\overline{\mathrm{PRS}^{1}}$ & Lb. acidophilus ATCC 20552 & $5.12 \pm 0.89^{* * * *}$ & $13.83 \pm 1.43^{* * * *}$ & $44.09 \pm 2.22^{* * * *}$ & $60.49 \pm 2.63^{* * * *}$ \\
\hline L1 & E. mediterraneensis & $3.82 \pm 0.11^{* * *}$ & $15.24 \pm 3.51^{* * *}$ & $27.96 \pm 3.89^{* * *}$ & $50.25 \pm 3.33^{* * *}$ \\
\hline L2 & & $6.08 \pm 3.36^{* * * *}$ & $16.64 \pm 2.62^{* * * *}$ & $33.29 \pm 2.78^{* * * *}$ & $62.76 \pm 1.13^{* * * *}$ \\
\hline L3 & & $4.66 \pm 1.58^{* *}$ & $9.33 \pm 3.17^{* *}$ & $21.46 \pm 3.42^{* *}$ & $28.92 \pm 2.12^{* *}$ \\
\hline L11 & & $5.88 \pm 0.08^{* * * *}$ & $14.69 \pm 1.36^{* * * *}$ & $51.47 \pm 0.75^{* * * *}$ & $64.71 \pm 0.95^{* * * *}$ \\
\hline L12 & & $5.11 \pm 0.81^{* * * *}$ & $12.27 \pm 2.89^{* * * *}$ & $41.51 \pm 2.15^{* * * *}$ & $60.5 \pm 1.08^{* * * *}$ \\
\hline L15 & & $4.63 \pm 0.11^{* * * *}$ & $13.34 \pm 3.59^{* * * *}$ & $40.65 \pm 3.79^{* * * *}$ & $63.91 \pm 2.06^{* * * *}$ \\
\hline L16 & & $5.84 \pm 1.81^{* * * *}$ & $16.49 \pm 1.92^{* * * *}$ & $40.93 \pm 3.32^{* * * *}$ & $60.11 \pm 1.29^{* * * *}$ \\
\hline$\llcorner 4$ & Lb. fermentum & $6.0 \pm 0.10^{* *}$ & $13.01 \pm 1.86^{* *}$ & $23.02 \pm 2.11^{* *}$ & $34.99 \pm 1.53^{* *}$ \\
\hline L5 & & $6.54 \pm 1.83^{* *}$ & $12.13 \pm 2.14^{* *}$ & $22.07 \pm 2.6^{* *}$ & $41.46 \pm 3.07^{* *}$ \\
\hline L8 & & $4.18 \pm 0.93^{* * *}$ & $15.20 \pm 2.62^{* * *}$ & $35.59 \pm 1.27^{* * *}$ & $51.26 \pm 2.53^{* * *}$ \\
\hline L9 & & $6.54 \pm 1.59^{* * *}$ & $16.35 \pm 3.01^{* * *}$ & $40.98 \pm 1.42^{* * *}$ & $55.19 \pm 2.08^{* * *}$ \\
\hline L10 & & $4.61 \pm 0.06^{* * * *}$ & $15.38 \pm 0.23^{* * * *}$ & $51.79 \pm 0.44^{* * * *}$ & $63.61 \pm 2.65^{* * * *}$ \\
\hline L13 & Strep. lutetiensis & $6.75 \pm 1.36^{* *}$ & $12.58 \pm 1.13^{* *}$ & $20.21 \pm 6.76^{* *}$ & $35.78 \pm 5.11^{* *}$ \\
\hline L14 & & $5.87 \pm 1.41^{* * * *}$ & $11.76 \pm 0.17^{* * * *}$ & $39.68 \pm 2.04^{* * * *}$ & $61.74 \pm 1.8^{* * * *}$ \\
\hline
\end{tabular}

1: probiotic reference strain. Data are expressed as mean \pm SD (standard deviation). ${ }^{*} P$ values were ${ }^{<} 0.05$.

For E. coli, the co-aggregation ability ranged from $25.29 \pm 7.43$ to $53.53 \pm 1.33 \%$ and from $20.29 \pm 5.34$ to $35.85 \pm 0.77 \%$ for $E$. mediterraneensis and Lb. fermentum, respectively. The highest co-aggregation, represented by $53.53 \pm 1.33,35.85 \pm 0.77$, and $45.76 \pm 1.92 \%$, were demonstrated for E. mediterraneensis (L15), Lb. fermentum (L8), and Strep. lutetiensis (L14), respectively.
For toxigenic bacteria, S. aureus and B. cereus, the results indicated that the maximum co-aggregation ability of E. mediterraneensis (L12) with S. aureus reached after $4 \mathrm{~h}$ and continued until $24 \mathrm{~h}$ (Table 9). After $24 \mathrm{~h}$, the co-aggregation ability of $E$. mediterraneensis with $S$. aureus and B. cereus ranged from $15.62 \pm 5.57$ to $44.29 \pm$ $2.96 \%$ and from $16.39 \pm 7.91$ to $49.68 \pm 2.65 \%$,

Table 8 Co-aggregation ability between isolated $L A B$ and enteric bacteria Sal. typhimurium and E. coli O157:H7

\begin{tabular}{|c|c|c|c|c|c|c|c|}
\hline \multirow{2}{*}{$\begin{array}{l}\text { Isolate } \\
\text { no. }\end{array}$} & \multirow[t]{2}{*}{ Isolate identification } & \multicolumn{3}{|c|}{ Co-aggregation (\%) with Sal. typhimurium } & \multicolumn{3}{|c|}{ Co-aggregation (\%) with E. coli 0157:H7 } \\
\hline & & $2 \mathrm{~h}$ & $4 \mathrm{~h}$ & $24 \mathrm{~h}$ & $2 \mathrm{~h}$ & $4 \mathrm{~h}$ & $24 \mathrm{~h}$ \\
\hline$\overline{\mathrm{PRS}^{1}}$ & Lb. acidophilus ATCC 20552 & $43.43 \pm 0.38^{* * * *}$ & $53.74 \pm 2.25^{* * * *}$ & $56.02 \pm 1.62^{* * * *}$ & $41.65 \pm 3.21^{* * * *}$ & $46.81 \pm 2.79^{* * * *}$ & $52.51 \pm 3.62^{* * * *}$ \\
\hline L1 & E. mediterraneensis & $30.16 \pm 2.75^{* *}$ & $38.35 \pm 2.74^{* *}$ & $50.31 \pm 2.72^{* *}$ & $18.86 \pm 0.36^{*}$ & $22.63 \pm 1.72^{*}$ & $27.02 \pm 1.77^{*}$ \\
\hline L2 & & $34.75 \pm 3.42^{* * *}$ & $40.27 \pm 2.91^{* * *}$ & $62.95 \pm 1.35^{* * *}$ & $31.48 \pm 1.13^{* *}$ & $36.99 \pm 1.48^{* *}$ & $39.73 \pm 2.02^{* *}$ \\
\hline L3 & & $10.29 \pm 5.98^{*}$ & $15.57 \pm 6.71^{*}$ & $16.39 \pm 7.91^{*}$ & $11.19 \pm 5.68^{*}$ & $19.28 \pm 4.33^{*}$ & $25.29 \pm 7.43^{*}$ \\
\hline L11 & & $29.64 \pm 4.26^{* *}$ & $42.41 \pm 0.66^{* *}$ & $53.1 \pm 3.18^{* *}$ & $12.61 \pm 1.67^{*}$ & $20.12 \pm 4.94^{*}$ & $27.78 \pm 2.96^{*}$ \\
\hline L12 & & $50.51 \pm 2.59^{* * * *}$ & $55.69 \pm 2.42^{* * * *}$ & $55.69 \pm 2.42^{* * * *}$ & $39.03 \pm 2.28^{* * * *}$ & $44.82 \pm 0.18^{* * * *}$ & $51.66 \pm 2.88^{* * * *}$ \\
\hline L15 & & $39.47 \pm 1.2^{* * * *}$ & $48.1 \pm 1.23^{* * * *}$ & $62.13 \pm 2.73^{* * * *}$ & $41.58 \pm 2.47^{* * * *}$ & $48.10 \pm 1.23^{* * * *}$ & $53.53 \pm 1.33^{* * * *}$ \\
\hline L16 & & $44.92 \pm 2.93^{* * * *}$ & $47.33 \pm 2.36^{* * * *}$ & $55.60 \pm 1.78^{* * * *}$ & $20.66 \pm 3.74^{*}$ & $27.17 \pm 3.08^{*}$ & $32.49 \pm 2.96^{*}$ \\
\hline$\llcorner 4$ & Lb. fermentum & $7.99 \pm 6.32^{*}$ & $17.04 \pm 3.67^{*}$ & $20.04 \pm 3.72^{*}$ & $9.89 \pm 6.15^{*}$ & $15.85 \pm 5.68^{*}$ & $22.95 \pm 4.26^{*}$ \\
\hline L5 & & $9.45 \pm 6.79^{*}$ & $20.48 \pm 1.79^{*}$ & $26.53 \pm 3.03^{*}$ & $5.85 \pm 3.46^{*}$ & $13.56 \pm 3.07^{*}$ & $20.29 \pm 5.34^{*}$ \\
\hline L8 & & $37.99 \pm 3.14^{* * *}$ & $47.81 \pm 1.27^{* * *}$ & $49.45 \pm 1.25^{* * *}$ & $31.48 \pm 2.74^{* *}$ & $33.11 \pm 2.7^{* *}$ & $35.85 \pm 0.77^{* *}$ \\
\hline L9 & & $34.30 \pm 2.83^{* * *}$ & $39.78 \pm 4.46^{* * *}$ & $42.84 \pm 5.24^{* * *}$ & $18.4 \pm 1.76^{* *}$ & $29.98 \pm 3.76^{* *}$ & $35.51 \pm 3.61^{* *}$ \\
\hline L10 & & $43.54 \pm 1.4^{* * * *}$ & $48.38 \pm 1.4^{* * * *}$ & $48.38 \pm 1.4^{* * * *}$ & $23.1 \pm 1.56^{*}$ & $24.71 \pm 1.54^{*}$ & $27.94 \pm 1.5^{*}$ \\
\hline L13 & Strep. Iutetiensis & $9.03 \pm 6.01^{*}$ & $18.09 \pm 4.85^{*}$ & $18.09 \pm 4.85^{*}$ & $11.11 \pm 3.5^{*}$ & $16.17 \pm 1.79^{*}$ & $24.22 \pm 2.76^{*}$ \\
\hline L14 & & $40.32 \pm 2.84^{* * *}$ & $45.16 \pm 0.63^{* * *}$ & $45.16 \pm 0.63^{* * *}$ & $31.92 \pm 0.69^{* * *}$ & $38.53 \pm 2.01^{* * *}$ & $45.76 \pm 1.92^{* * *}$ \\
\hline
\end{tabular}

1: probiotic reference strain. Data are expressed as mean $\pm S D$ (standard deviation). ${ }^{*} P$ values were $<0.05$. 
Table 9 Co-aggregation ability between isolated $L A B$ and toxigenic bacteria S. aureus and B. cereus

\begin{tabular}{|c|c|c|c|c|c|c|c|}
\hline \multirow{2}{*}{$\begin{array}{l}\text { Isolate } \\
\text { no. }\end{array}$} & \multirow[t]{2}{*}{ Isolate identification } & \multicolumn{3}{|c|}{ Co-aggregation (\%) with S. aureus } & \multicolumn{3}{|c|}{ Co-aggregation (\%) with B. cereus } \\
\hline & & $2 \mathrm{~h}$ & $4 \mathrm{~h}$ & $24 \mathrm{~h}$ & $2 \mathrm{~h}$ & $4 \mathrm{~h}$ & $24 \mathrm{~h}$ \\
\hline PRS & Lb. acidophilus ATCC 20552 & $38.8 \pm 4.42^{* * *}$ & $40.52 \pm 4.39^{* * *}$ & $43.38 \pm 3.52^{* * *}$ & $38.8 \pm 4.42^{* * *}$ & $41.07 \pm 5.26^{* * *}$ & $44.5 \pm 5.20^{* * *}$ \\
\hline L1 & E. mediterraneensis & $32.69 \pm 0.63^{* * *}$ & $34.58 \pm 0.61^{* * *}$ & $38.98 \pm 0.58^{* * *}$ & $18.24 \pm 1.14^{*}$ & $22.63 \pm 1.72^{*}$ & $27.02 \pm 1.77^{*}$ \\
\hline L2 & & $38.61 \pm 2.97^{* * * *}$ & $39.69 \pm 3.67^{* * * *}$ & $44.13 \pm 2.7^{* * * *}$ & $24.76 \pm 4.17^{* *}$ & $30.87 \pm 2.86^{* *}$ & $34.19 \pm 2.75^{* *}$ \\
\hline L3 & & $9.48 \pm 4.61^{*}$ & $12.15 \pm 4.4^{*}$ & $15.62 \pm 5.57^{*}$ & $11.10 \pm 7.37^{*}$ & $16.39 \pm 7.91^{*}$ & $16.39 \pm 7.91^{*}$ \\
\hline L11 & & $29.04 \pm 3.87^{* *}$ & $30.94 \pm 3.82^{* *}$ & $34.09 \pm 3.76^{* *}$ & $29.62 \pm 4.57^{* * *}$ & $34.76 \pm 1.52^{* * *}$ & $47.39 \pm 3.34^{* * *}$ \\
\hline $\mathrm{L} 12$ & & $39.58 \pm 3.35^{* * *}$ & $41.31 \pm 3.3^{* * *}$ & $41.31 \pm 3.3^{* * *}$ & $40.77 \pm 1.29^{* * *}$ & $42.5 \pm 1.24^{* * *}$ & $47.63 \pm 2.73^{* * *}$ \\
\hline L15 & & $41.05 \pm 3.00^{* * * *}$ & $42.67 \pm 2.98^{* * * *}$ & $44.29 \pm 2.96^{* * * *}$ & $41.56 \pm 3.07^{* * * *}$ & $44.82 \pm 2.76^{* * * *}$ & $49.68 \pm 2.65^{* * * *}$ \\
\hline L16 & & $29.5 \pm 4.58^{* *}$ & $32.48 \pm 3.57^{* *}$ & $34.85 \pm 3.58^{* *}$ & $39.00 \pm 2.51^{* * *}$ & $43.18 \pm 1.41^{* * *}$ & $48.46 \pm 3.14^{* * *}$ \\
\hline$\llcorner 4$ & Lb. fermentum & $10.85 \pm 6.7^{*}$ & $14.89 \pm 4.81^{*}$ & $17.90 \pm 4.71^{*}$ & $5.91 \pm 2.72^{*}$ & $15.85 \pm 5.68^{*}$ & $24.86 \pm 5.33^{*}$ \\
\hline L5 & & $5.85 \pm 3.46^{*}$ & $7.52 \pm 3.79^{*}$ & $10.09 \pm 3.62^{*}$ & $7.43 \pm 6.08^{*}$ & $20.48 \pm 1.79^{*}$ & $26.53 \pm 3.03^{*}$ \\
\hline L8 & & $39.09 \pm 1.89^{* * * * *}$ & $40.73 \pm 1.86^{* * * *}$ & $44.55 \pm 1.74^{* * * * *}$ & $34.76 \pm 1.87^{* * *}$ & $39.65 \pm 1.80^{* * *}$ & $48.91 \pm 1.25^{* * *}$ \\
\hline L9 & & $34.93 \pm 2.24^{* * *}$ & $36.76 \pm 2.2^{* * *}$ & $38.61 \pm 2.15^{* * *}$ & $35.55 \pm 2.09^{* * *}$ & $40.45 \pm 2.11^{* * *}$ & $45.97 \pm 1.97^{* * *}$ \\
\hline L10 & & $40.29 \pm 2.27^{* * * * *}$ & $41.91 \pm 2.25^{* * * *}$ & $45.12 \pm 3.56^{* * * * *}$ & $33.31 \pm 1.41^{* * *}$ & $44.58 \pm 3.35^{* * *}$ & $51.58 \pm 2.39^{* * *}$ \\
\hline L13 & Strep. Iutetiensis & $11.11 \pm 3.5^{*}$ & $15.13 \pm 2.86^{*}$ & $20.15 \pm 4.32^{*}$ & $14.05 \pm 4.24^{*}$ & $17.08 \pm 4.14^{*}$ & $21.12 \pm 4.78^{*}$ \\
\hline L14 & & $33.68 \pm 2.8^{* *}$ & $35.48 \pm 2.75^{* *}$ & $37.32 \pm 1.14^{* *}$ & $34.89 \pm 2.96^{* *}$ & $37.28 \pm 3.59^{* *}$ & $40.31 \pm 2.84^{* *}$ \\
\hline
\end{tabular}

1: probiotic reference strain. Data are expressed as mean $\pm \mathrm{SD}$ (standard deviation). ${ }^{*} P$ values were ${ }^{`} 0.05$.

respectively. On the other hand, $L b$. fermentum isolates had the ability to aggregate with $S$. aureus and $B$. cereus in a range of $10.09 \pm 3.62$ to $45.12 \pm 3.56 \%$ and $24.86 \pm$ 5.33 to $51.58 \pm 2.39 \%$, correspondingly. The greatest coaggregation of $44.29 \pm 2.96,45.12 \pm 3.56$, and $37.32 \pm$ $1.14 \%$ was observed between $S$. aureus and each of $E$. mediterraneensis (L15), Lb. fermentum (L10), and Strep. lutetiensis (L14), individually. For B. cereus, the strongest co-aggregation, signified by $49.68 \pm 2.65,51.58 \pm 2.39$, and $40.31 \pm 2.84 \%$, were established with $E$. mediterraneensis (L15), Lb. fermentum (L10), and Strep. lutetiensis (L14), respectively.

\section{Antimicrobial activity assay}

Three extracts, prepared from each isolated LAB, were employed to assess the antibacterial activity against

Table 10 Inhibitory effect of the extracts prepared from isolated $L A B$

\begin{tabular}{|c|c|c|c|c|c|c|c|c|c|c|c|c|c|}
\hline \multirow{3}{*}{$\begin{array}{l}\text { Isolate } \\
\text { no. }\end{array}$} & \multirow[t]{3}{*}{ Isolate identification } & \multicolumn{12}{|c|}{ Diameter of inhibition zone $(\mathrm{mm})$} \\
\hline & & \multicolumn{3}{|c|}{ Sal. typhimurium } & \multicolumn{3}{|c|}{ E. coli 0157:H7 } & \multicolumn{3}{|c|}{ B. cereus } & \multicolumn{3}{|c|}{ S. aureus } \\
\hline & & $\overline{E 1}$ & E2 & E3 & $\overline{\mathrm{E} 1}$ & E2 & E3 & E1 & E2 & $\overline{E 3}$ & E1 & E2 & E3 \\
\hline$\overline{\mathrm{PRS}^{1}}$ & Lb. acidophilus ATCC 20552 & 23 & 21 & 11 & 24 & 22 & 11 & 21 & 19 & 12 & 22 & 21 & 11 \\
\hline L1 & E. mediterraneensis & 16 & 15 & $\mathrm{R}$ & 12 & 12 & $\mathrm{R}$ & 13 & 12 & $\mathrm{R}$ & 12 & 11 & $\mathrm{R}$ \\
\hline L2 & & 14 & 12 & $\mathrm{R}$ & 13 & 11 & $\mathrm{R}$ & 14 & 14 & $\mathrm{R}$ & 12 & 11 & $\mathrm{R}$ \\
\hline L3 & & $\mathrm{R}$ & $\mathrm{R}$ & $\mathrm{R}$ & $\mathrm{R}$ & $\mathrm{R}$ & $\mathrm{R}$ & $\mathrm{R}$ & $\mathrm{R}$ & $\mathrm{R}$ & $\mathrm{R}$ & $\mathrm{R}$ & $\mathrm{R}$ \\
\hline L11 & & 23 & 21 & 13 & 19 & 17 & 13 & 20 & 19 & 12 & 19 & 17 & 13 \\
\hline L12 & & 15 & 13 & $\mathrm{R}$ & 22 & 22 & 12 & 15 & 14 & 11 & 16 & 15 & 11 \\
\hline L15 & & 25 & 24 & 14 & 29 & 28 & 12 & 18 & 13 & 11 & 19 & 17 & 11 \\
\hline L16 & & 24 & 24 & 12 & 17 & 16 & 13 & 19 & 20 & 11 & 18 & 16 & 12 \\
\hline L4 & Lb. fermentum & $\mathrm{R}$ & $\mathrm{R}$ & $\mathrm{R}$ & $\mathrm{R}$ & $\mathrm{R}$ & $\mathrm{R}$ & $\mathrm{R}$ & $\mathrm{R}$ & $\mathrm{R}$ & $\mathrm{R}$ & $\mathrm{R}$ & $\mathrm{R}$ \\
\hline L5 & & $\mathrm{R}$ & $\mathrm{R}$ & $\mathrm{R}$ & $\mathrm{R}$ & $\mathrm{R}$ & $\mathrm{R}$ & $\mathrm{R}$ & $\mathrm{R}$ & $\mathrm{R}$ & $\mathrm{R}$ & $\mathrm{R}$ & $\mathrm{R}$ \\
\hline L8 & & 18 & 19 & 12 & $\mathrm{R}$ & $\mathrm{R}$ & $\mathrm{R}$ & 22 & 20 & 15 & 19 & 17 & 11 \\
\hline L9 & & 20 & 21 & 13 & 17 & 16 & 12 & 15 & 14 & 11 & 16 & 15 & 11 \\
\hline L10 & & 16 & 15 & 11 & $\mathrm{R}$ & $\mathrm{R}$ & $\mathrm{R}$ & $\mathrm{R}$ & $\mathrm{R}$ & $\mathrm{R}$ & 18 & 16 & 12 \\
\hline L13 & Strep. Iuteliensis & $\mathrm{R}$ & $\mathrm{R}$ & $\mathrm{R}$ & $\mathrm{R}$ & $\mathrm{R}$ & $\mathrm{R}$ & $\mathrm{R}$ & $\mathrm{R}$ & $\mathrm{R}$ & $\mathrm{R}$ & $\mathrm{R}$ & $\mathrm{R}$ \\
\hline L14 & & 22 & 21 & 12 & 21 & 19 & 11 & 14 & 12 & $\mathrm{R}$ & 19 & 17 & 11 \\
\hline
\end{tabular}


aforementioned pathogenic bacteria. Extract 1 was crude extract that might contain $\mathrm{H}_{2} \mathrm{O}_{2}$, organic acids, and bacteriocins; extract 2 was crude extract that could contain organic acids and bacteriocins, whereas extract 3 was crude bacteriocin. The results in Table 10 revealed that all extracts prepared from E. mediterraneensis (L11, L15, and L16) and Lb. fermentum (L9) displayed antagonistic activity against all selected bacterial pathogens with inhibition zone which ranged from 11 to $29 \mathrm{~mm}$ in diameter. Also, all extracts of E. mediterraneensis (L12), $L b$. fermentum (L8), and Strep. luteliensis (L14) exhibited antibacterial effect against all pathogens, except Sal. typhimurium, E. coli $\mathrm{O} 157: \mathrm{H} 7$, and B. cereus, respectively. All extracts of Lb. fermentum (L10) had antimicrobial effect against Sal. typhimurium and S. aureus only.

All indicator pathogenic bacteria were entirely resistant to E. mediterraneensis (L3), Lb. fermentum (L4 and L5) and Strep. lutetiensis (L13). Extract 3 prepared from E. mediterraneensis (L1 and L2) had no antagonistic activity against all tested pathogens.

\section{Discussion}

Generally, lactic acid bacteria (LAB) are the main group of probiotics used for humans and animals. In the food fermentation, they play a significant role by inhibiting the growth of spoilage/pathogenic microorganisms, and by producing fermented food products with desired flavor, aroma, and texture.

Usually, the probiotic microorganisms are screened from food and nonfood sources. The nonfood sources include gastrointestinal tract, as the main nonfood source, honeycomb, soil and plant surface. On the other hand, the food sources are represented by fermented dairy, meat and vegetable products, and fruit juices.

In the present study, after performing Gram staining, catalase test and blood hemolysis test, the DNA fingerprinting and $16 \mathrm{~S}$ rRNA gene sequencing were applied to identify 16 acid and bile salt-tolerant bacteria isolated from different food sources. The results revealed that, 43.75\% were identified as Enterococcus mediterraneensis isolated from rayeb milk, kareish cheese, and frankfurte. Also, 31.25\% were classified as Lactobacillus fermentum isolated from rayeb milk, yoghurt, and frankfurter. Both Streptococcus lutetiensis and Bacillus circulans represented $12.5 \%$ of the total isolates. Enterococcus mediterraneensis was first isolated and identified in 2019 from the stool of a 39-year-old male Pygmy in the Democratic Republic of Congo [21]. There are no previous studies reporting isolation of E. mediterraneensis from Egyptian sources. Therefore, this study is considered as the first one to isolate Enterococcus mediterraneensis in Egypt and to characterize its probiotic properties worldwide.

Streptococcus lutetiensis is belonging to Streptococcus bovis/Streptococcus equinus complex (SBSEC) which is a non-enterococcal group D Streptococcus spp. complex. The strains of SBSEC are commensal colonizers of the gastrointestinal tract of humans and animals including ruminants as cattle, sheep, goats, and camels. Some strains of SBSEC have been associated with different diseases as endocarditis, bacteremia, biliary tract, prosthetic joint infections, meningitis, and diarrhea. Additionally, some strains are considered as important species having a main role in the quality of fermented food products. Moreover, some SBSEC strains as Strep. lutetiensis and Strep. gallolyticus subsp. macedonicus are consumed as a part of the daily diet. Consequently, they are considered to be safe for human consumption [22, 23]. For blood hemolysis activity, some strains are gamma-hemolytic (non-hemolytic), which agreed with the results of the present study, and some exhibit alpha-hemolytic activity.

The representatives of various Bacillus species have a long history of safe use as probiotics. Globally, there is a variety of commercial formulations containing Bacillus spp. to be used as probiotics [24]. Bacillus circulans, reported to cause human infection, is a member of the $B a$ cillus subtilis group [25]. Most species of this group exhibit $\beta$-hemolytic activity. In this study, Bacillus circulans was isolated from frankfurter and exhibited $\gamma$ hemolysis on blood agar. This result was in agreement with the findings of Alebouyeh et al. [26] who isolated nonhemolytic $B$. circulans from a 62-year-old patient with 4 years of unknown end-stage renal disease. It is known that Bacillus circulans is an opportunistic pathogen found in soil, sewage, and food. Also, many previous studies isolated B. circulans from cases of meningitis, prosthetic heart valve [27], endocarditis, endophthalmitis [28], and wound infection. There are other reports indicating that $B$. circulans is a causative agent of sepsis in immunocompromised hospitalized patients [24].

This study reported the isolation of Clavispora lusitaniae from kareish cheese. Clavispora lusitaniae, which is also known as Candida lusitaniae, could be isolated from different sources as digestive tract, fruit juices, citrus peel, and milk from cow infected with mastitis. Generally, Clavispora lusitaniae is considered as a nosocomial pathogen [29].

Generally, the microorganisms are considered as safe and beneficial probiotics for human and animal use after their proper identification and characterization. Consequently, in vitro characterization of safety and functional properties is extremely imperative for the selection of highly effective probiotic strains. In the current study, the functional assays to evaluate the probiotic efficiency of isolated B. circulans and Clavispora lusitaniae were not performed because they are stated as microbial pathogens as was previously mentioned.

Lacking the hemolytic activity is one of the most important safety characteristics recommended by $\mathrm{FAO} /$ 
WHO (2002) for probiotic microorganisms to be considered as food grade bacteria [30]. Actually, all lactic acid bacterial isolates (14 isolates) were nonhemolytic isolates. The absence of hemolytic activity of isolated $E$. mediterraneensis was in agreement with the previous study of Takakura et al. [21].

Evaluating the antibiotic susceptibility is considered as the second important safety aspect regarding employing the bacteria as probiotics in food and animal feed. The results revealed that the isolates of $E$. mediterraneensis were susceptible to ampicillin and ceftolozane inhibiting the cell wall biosynthesis, and to neomycin inhibiting the protein synthesis, unlike the other enterococci reported by Miller et al. [31] to have innate resistance to antibiotics of $\beta$-lactams and aminoglycosides. All Lb. fermentum isolates exhibited susceptibility to ceftolozane, neomycin, and sulphamethoxazole inhibiting the cell wall and protein biosynthesis and folic acid metabolism, respectively. These results were in agreement with previous studies of Danielsen and Wind [32] and Abriouel et al. [33]. The two isolates of Strep. lutetiensis displayed sensitivity to antibiotics with mode of action to inhibit the biosynthesis of cell wall and proteins.

Antibiotic resistance of probiotics and absence of transferable antibiotic resistance genes, that could be transferred horizontally to other bacteria, are imperative to avoid the risk of prevalence of antibiotic resistance genes in the environment and to confirm the safety of probiotic application as food and feed additives [34]. European Centre for Disease Prevention and Control (ECDC) and the Centers for Disease Control and Prevention (CDC) defined the multidrug resistance (MDR) as the resistance to at least one agent in three or more antimicrobial categories [35]. According to this definition, E. mediterraneensis isolates (L3, L11, L12, and L16), all isolated Lb. fermentum and Strep. lutetiensis are regarded as multidrug-resistant bacteria. Generally, lactobacilli are known to have intrinsic resistance to vancomycin [36, 37]. The genes encoding its resistance are located on the chromosome which indicates these genes are not transferred horizontally. On the other hand, genes encoding the tetracycline resistance are often located on the conjugative plasmids [38]. Therefore, they could be transferred.

Phenol and its derivatives are known to have antibacterial and antifungal activity. Therefore, evaluating the resistance of potential probiotics to phenol is significant to be applied in animal and fish feeding as these compounds are produced in their intestine by bacterial deamination of aromatic amino acids liberated during digestion of dietary proteins [39]. In the present study, the highest survival rate to $0.4 \%$ phenol was recorded with $E$. mediterraneensis (L16), Lb. fermentum (L9), and Strep. lutetiensis (L14).
Survival in the gastrointestinal juice, cell surface hydrophobicity (CSH), and capability to autoaggregate are the foremost selective traits of potential probiotics to be functionally effective in the host. Evaluating the performance of probiotic candidates in simulated gastrointestinal environment is essential to sufficiently predict their in vivo behavior as without this property the microorganisms will not be functionally influential [17]. Some studies have evaluated the resistance of probiotics to the gastrointestinal juices through using the gastric and intestinal juices individually $[16,40]$. In this study, the successive gastric and intestinal digestion was employed to simulate the physiological conditions of human and animal gastrointestinal digestion. The simulated gastric conditions were characterized by the presence of $0.3 \%$ bile salt and $0.1 \%$ pepsin enzyme in acidic conditions $(\mathrm{pH}$ $2.5)$, whereas the simulated intestinal conditions were represented by the presence of $1 \%$ pancreatin containing trypsin, lipase, protease, and amylase enzymes in higher $\mathrm{pH}$ of 6.8 . The tolerance of potential probiotics, used in fish aquaculture and animal feeding, to bile salt is substantial not only to confirm their ability to survive in the indigenous bile salt present naturally in fish and animal intestine, but also to that added to animal and fish feeds. Recently, the plant feed ingredients, supplemented with bile salt, are employed to replace fishmeal and fish oil in feed production. This supplementation is very essential because some compounds for bile salt synthesis, as cholesterol and taurine, are usually insufficient in plant feed ingredients [41]. The results revealed that some isolates have high survivability that reached $23.9 \pm 1.85$ and $32.73 \pm$ $0.84 \%$ for $L b$. fermentum (L8) and E. mediterraneensis (L2), respectively. Conversely, the low survival rates of $2.01 \pm 0.01$ and $1.35 \pm 0.06 \%$ were recorded for $L b$. fermentum (L9) and E. mediterraneensis (L16), correspondingly. The low survivability may be attributed to the antimicrobial effect of bile salts which causes permeabilization of the bacterial cell membrane and leakage of cytosol consequently. Some researchers reported that the effect of bile salt on the bacterial cytoplasmic membrane depends on its concentration. The high concentrations dissolve membrane lipids, causing leakage of cell materials and cell death. Low concentrations have less undesirable effects on the membrane fluidity and permeability by changing membrane proteins or increasing transmembrane divalent cation flow [42]. According to Botta et al. [17] who reported that the microorganisms with ODS less than $0.00001 \%$, after sequential transfer from gastric to intestinal juice, are not considered resistant to the gastrointestinal conditions, all E. mediterraneensis, $L b$. fermentum, and Strep. lutetiensis isolates have an 
extremely considerable resistance as the lowest ODS value was $1.35 \pm 0.06 \%$.

The high cell surface hydrophobicity and strong autoaggregation capability are considered as essential requirements of probiotics to ensure strong colonization and adhesion to intestinal epithelium of the host to provide their health benefits. Also, the strong adhesion to mucosal surfaces and epithelial cells of the gastrointestinal tract allows probiotics to overcome the gastric motility and therefore enhances the interactions between probiotic bacteria and host [43]. Generally, the cell surface hydrophobicity is different between bacterial species, but there are numerous compounds playing a main role in the bacterial CSH. These compounds include lipoteichoic acid, core oligosaccharides, outer membrane proteins and lipids, surface fibrils and several fimbriae [43]. Hydrophobicity is likely due to a complex interaction between positively charged, negatively charged, hydrophilic and hydrophobic components on the bacterial surface [44]. The studies of Jena et al. [16] and Abdulla et al. [44] reported that the bacterial strains, with more than $40 \%$ hydrophobicity, will be considered hydrophobic. According to their findings, E. mediterraneensis (L3), Lb. fermentum (L5), and Strep. lutetiensis (L13) could be considered as hydrophobic isolates as their $\mathrm{CSH}$, ranging from $37.87 \pm 9.71$ to $39.79 \pm 2.87 \%$, is slightly less than $40 \%$.

Bacterial auto-aggregation is defined as the ability of bacteria of the same strain to bind to themselves. This phenomenon is observed clearly through the formation of bacterial clumps that precipitate at the tube bottom. Generally, the auto-aggregation is mediated by exopolysaccharide and surface proteins as extracellular serine/ threonine-rich protein of $L b$. plantarum NCIMB 8826 [45] and S-layer proteins of Lb. acidophilus M92 [46]. The current study confirmed the findings of other studies reported that the self-aggregation increases with extending the incubation time $[16,44]$. The greatest autoaggregation ability, higher than $50 \%$, was recorded with $71.43 \%$ of isolated LAB. In another study, the strongest auto-aggregation ability reached $47.2 \pm 2.4 \%$ [16].

Although some studies [44, 47, 48] reported the direct correlation between bacterial cell surface hydrophobicity and auto-aggregation capability, the results of this study do not support the hypothesis as relation of the autoaggregation and CSH was not characterized.

The auto-aggregation and co-aggregation (aggregation between genetically different strains) are considered as key properties of probiotics to prevent colonization of gastrointestinal tract with pathogens. This is due to the formation of biofilms of auto-aggregating bacteria on the intestinal mucosa and intercellular adhesion between coaggregating bacteria and microbial pathogens [49]. Thence, aggregation could be counted as one of the defense mechanisms of host for anti-infection. In this work, the E. mediterraneensis isolates (L2, L12, and L15) with high auto-aggregation ability exhibited high coaggregation capability with Sal. typhimurium, E. coil O157:H7, S. aureus, and B. cereus in a range of $55.69 \pm$ 2.42 to $62.95 \pm 1.35,39.73 \pm 2.02$ to $53.53 \pm 1.33,41.31$ \pm 3.3 to $44.29 \pm 2.96$ and $34.19 \pm 2.75$ to $49.68 \pm 2.65 \%$, respectively. Also, the Lb. fermentum isolates (L8, L9, and L10) with high auto-aggregation ability exhibited high co-aggregation with Sal. typhimurium, E. coil O157:H7, S. aureus, and B. cereus in a range of $42.84 \pm$ 5.24 to $49.45 \pm 1.25,27.94 \pm 1.5$ to $35.85 \pm 0.77,38.61 \pm$ 2.15 to $45.12 \pm 3.56$ and $45.97 \pm 1.97$ to $48.91 \pm 1.25 \%$, individually. The isolate Strep. lutetiensis (L14) displayed high auto-aggregation of $61.74 \pm 1.8 \%$ and coaggregation of $45.16 \pm 0.63,45.76 \pm 1.92,37.32 \pm 1.14$, and $40.31 \pm 2.84 \%$ with Sal. typhimurium, E. coil O157: $\mathrm{H} 7$, S. aureus, and B. cereus, correspondingly. Thus, these isolates possessing the strong ability to autoaggregate and co-aggregate pathogens could be valuable to the intestinal health.

The relation between probiotics and pathogenic bacteria depends on the co-aggregation and antimicrobial activity of probiotics to inhibit pathogens. The isolates of prospective probiotic LAB should exhibit manifest antimicrobial activities against pathogenic bacteria causing diseases in human and animal gut to improve the host health and to balance the gut microbiota. In this study, 85.71 and 50\% of E. mediterraneensis and Strep. lutetiensis isolates, respectively displayed antibacterial activity against all selected bacterial pathogens. For $L b$. fermentum isolates, 40 and $20 \%$ had effect against B. cereus and E. coli O157: H7, correspondingly. Furthermore, $60 \%$ were active against both Sal. typhimurium and $S$. aureus. The antibacterial activity of extracts prepared from $\mathrm{LAB}$ was evaluated to specify the antimicrobial agents. No inhibitory effect was observed from extract 3 prepared from $E$. mediterraneensis (L1 and L2), (L12), and Strep. luteliensis (L14) against all tested pathogens, Sal. typhimurium and B. cereus, respectively. Absence of the antagonistic activity of the third extract indicates the antimicrobial effect attributed mainly to organic acids only or organic acids and $\mathrm{H}_{2} \mathrm{O}_{2}$ as organic acids are present in the first and second extracts but $\mathrm{H}_{2} \mathrm{O}_{2}$ is found in the first extract only. According to the obtained results, $57.14 \%$ of $E$. mediterraneensis isolates (L11, L12, L15, and L16) could be considered bacteriocinogenic against $E$. coli $\mathrm{O} 157: \mathrm{H7}$, B. cereus, and S. aureus, whereas $42.86 \%$ (L11, L15, and L16) was bacteriocinogenic against Sal. typhimurium. For Lb. fermentum, 60\% (L8, L9, and L10) could be characterized as bacteriocinogenic isolates against Sal. typhimurium and S. aureus, 40\% (L8 and L9) against B. cereus and finally 20\% (L9) against E. coli O157:H7. Also, Strep. lutetiensis (L14) 
could be specified as bacteriocinogenic against all tested bacterial pathogens. Many studies demonstrated the antagonistic effect of LAB against different pathogens through production of various antimicrobial agents including carbon dioxide, hydrogen peroxide, organic acids, and bacteriocins [17, 40, 43].

\section{Conclusion}

The results collectively revealed that $E$. mediterraneensis (L2, L12, and L15), Lb. fermentum (L8, L9, and L10), and Strep. lutetiensis (L14) could be considered excellent probiotic candidates as they have promising properties essential for potential probiotics. In vivo experiments are recommended to evaluate functionality of the most promising isolates in human and animals. Actually, these experiments are considered as additionally safety tests to check all possibilities of using described probiotic species for human and animal diet supplementation.

\section{Abbreviations \\ Lb: Lactobacillus; E. mediterraneensis: Enterococcus mediterraneensis; Strep. lutetiensis: Streptococcus lutetiensis; AM: Ampicillin; CEF: Ceftolozane; CLI: Clindamycin; TE: Tetracycline; MXF: Moxifloxacin; NEO: Neomycin; SXT: Sulphamethoxazole; VAN: Vancomycin; CHL: Chloramphenicol; R: Resistant; S: Sensitive; I: Intermediate resistant}

\section{Acknowledgements}

Not applicable

\section{Availability of data and material}

The authors declare that all data supporting the findings of this study are included within the article.

\section{Authors' contributions}

Conceptualization: $\mathrm{GE}, \mathrm{HG}$, and $\mathrm{GKh}$; investigation: $\mathrm{AA}$ and $\mathrm{TE}$; data analysis: $A A$, TE, and HG; writing the original draft: TE and HG; writing - review and editing: $H G$ and GKh; supervision: GKh, HG, and GE. The authors have read and approved the manuscript.

\section{Funding}

Not applicable

\section{Declarations}

Ethics approval and consent to participate

Not applicable

\section{Consent for publication}

Not applicable

\section{Competing interests}

The authors declare that they have no competing interests.

\section{Author details}

${ }^{1}$ Agricultural Research Centre, Regional Centre for Food and Feed, Giza 12619, Egypt. ${ }^{2}$ Agricultural Microbiology Department, Faculty of Agriculture, Cairo University, Giza 12613, Egypt.

Received: 14 April 2021 Accepted: 19 July 2021

Published online: 05 August 2021

\section{References}

1. Hasler CM, Brown AC (2009) Position of the American Dietetic Association: functional foods. J Am Diet Assoc 109(4):735-746. https://doi.org/10.1016/j. jada.2009.02.023
2. Terpou A, Papadaki A, Lappa IK, Kachrimanidou V, Bosnea LA, Kopsahelis N (2019) Probiotics in food systems: significance and emerging strategies towards improved viability and delivery of enhanced beneficial value. Nutrients 11:1591. https://doi.org/10.3390/nu11071591

3. FAO/WHO (2001) Evaluation of health and nutritional properties of powder milk and live lactic acid bacteria. In: Food and Agriculture Organization of the United Nations and World Health Organization Expert Consultation Report Rome.

4. Gibson G, Hutkins R, Sanders E, Prescott S, Reimer A, Salminen J, Scott K, Stanton C, Swanson K, Cani P, Verbeke K, Reid G (2017) Expert consensus document: The International Scientific Association for Probiotics and Prebiotics (ISAPP) consensus statement on the definition and scope of prebiotics. Nat Rev Gastroenterol Hepatol 14(8):491-502. https://doi.org/10.1 038/nrgastro.2017.75

5. Grau T, Vilcinskas A, Joop G (2017) Probiotic Enterococcus mundtii isolate protects the model insect Tribolium castaneum against Bacillus thuringiensis. Front Microbiol 8. https://doi.org/10.3389/fmicb.2017.01261

6. Valdés-Varela L, Gueimonde M, Ruas-Madiedo P (2018) Probiotics for prevention and treatment of Clostridium difficile infection. In: Updates on Clostridium difficile in Europe p.161-76.

7. Sornplang P, Piyadeatsoontorn S (2016) Probiotic isolates from unconventional sources: a review. J Anim Sci Technol doi 58(1):26. https:// doi.org/10.1186/s40781-016-0108-2

8. Bacanli M, Basaran N (2019) Importance of antibiotic residues in animal food. Food Chem Toxicol 125:462-466. https://doi.org/10.1016/j.fct.2019.01.033

9. Reid G (2016) Probiotics: Definition, scope and mechanisms of action. Best Pract Res Clin Gastroenterol 30(1):17-25. https://doi.org/10.1016/j.bpg.201 5.12 .001

10. Markowiak P, Śliżewska K (2017) Effects of probiotics, prebiotics, and synbiotics on human health. Nutrients 9(9). https://doi.org/10.3390/nu9091 021

11. James A, Wang Y (2019) Characterization, health benefits and applications of fruits and vegetable probiotics. CyTA - J Food 17(1):770-780. https://doi. org/10.1080/19476337.2019.1652693

12. Rademaker J, de Bruijn F (1997) Characterization and classification of microbes by rep-PCR genomic fingerprinting and computer assisted pattern analysis. In: Caetano-Anollés G, Gresshoff P (eds) DNA Markers: Protocols, Applications and Overview. Wiley, New Jersey, pp 151-171

13. European Food Safety Authority (EFSA) (2012) Guidance on the assessment of bacterial susceptibility to antimicrobials of human and veterinary importance. EFSA J 10:2740

14. Clinical and Laboratory Standards Institute (CLSI), M100-S24 (2014) Performance standards for antimicrobial susceptibility testing.

15. Clinical and Laboratory Standards Institute (CLSI), M100- 27th edition (2017) Performance standards for antimicrobial susceptibility testing.

16. Jena PK, Trivedi D, Thakore K, Chaudhary H, Giri S, Seshadri S (2013) Isolation and characterization of probiotic properties of Lactobacilli isolated from rat fecal microbiota. Microbiol Immunol 57(6):407-416. https://doi.org/1 0.1111/1348-0421.12054

17. Botta C, Langerholc T, Cencic A, Cocolin L (2014) In vitro selection and characterization of new probiotic candidates from table olive microbiota. PLoS ONE doi 9(4):e94457. https://doi.org/10.1371/journal.pone.0094457

18. Kumar H, Rangrez A, Dayananda K, Atre A, Patole M, Shouche Y (2011) Lactobacillus plantarum (VR1) isolated from an Ayurvedic medicine (Kutajarista) ameliorates in vitro cellular damage caused by Aeromonas veronii. BMC Microbiol doi 11(1):152. https://doi.org/10.1186/1471-2180-11-1 52

19. Wang J, Yadav V, Smart A, Tajiri S, Basit A (2015) Toward oral delivery of biopharmaceuticals: an assessment of the gastrointestinal stability of 17 peptide drugs. Mol Pharm 12(3):966-973. https://doi.org/10.1021/mp500809f

20. Bauer AW, Kirby WM, Sherris JC, Turck M (1966) Antibiotic susceptibility testing by a standardized single disk method. Am J Clin Pathol 45(4_ts): 493-496. https://doi.org/10.1093/ajcp/45.4_ts.493

21. Takakura T, Francis R, Anani H, Bilen M, Raoult D, Bou Khalil J (2019) Enterococcus mediterraneensis sp. nov., a new bacterium isolated from the stool of a 39-year-old Pygmy. New Microbe and New Infect 32:100599. https://doi.org/10.1016/j.nmni.2019.100599

22. Jans C, Meile L, Lacroix C, Stevens M (2015) Genomics, evolution, and molecular epidemiology of the Streptococcus bovis/Streptococcus equinus complex (SBSEC). Infect Genet Evol 33:419-436. https://doi.org/10.1016/j. meegid.2014.09.017 
23. Jans C, Boleij A (2018) The road to infection: host-microbe interactions defining the pathogenicity of Streptococcus bovis/Streptococcus equinus complex members. Front Microbiol https://doi.org/10.3389/fmicb.2018. 00603

24. Celandroni F, Vecchione A, Cara A, Mazzantini D, Lupetti A, Ghelardi E (2019) Identification of Bacillus species: implication on the quality of probiotic formulations. PLoS One 14(5):e0217021. https://doi.org/10.1371/ journal.pone.0217021

25. Public Health England (PHE)/National Health Service (NHS) (2018) UK standards for microbiology investigations (identification of Bacillus species). ID: 9, Issue no.: 3.1, p. 1-27.

26. Alebouyeh M, Orimi P, Azimi-rad M, Tajbakhsh M, Tajeddin E, Sherafat S, Mojarad E, Zali M (2011) Fatal sepsis by Bacillus circulans in an immunocompromised patient. Iran J Microbiol 3:156-158

27. Krause A, Gould K, Forty J (1999) Prosthetic heart valve endocarditis caused by Bacillus circulans. J Inf Secur 39(2):160-162. https://doi.org/10.1016/s01 63-4453(99)90011-7

28. Tandon A, Tay-Kearney L, Metcalf C, McAllister L (2001) Bacillus circulans endophthalmitis. Clin Exp Ophthalmol 29(2):92-93. https://doi.org/10.1046/ j.1442-9071.2001.d01-10.x

29. Gómez J, García-Vázquez E, Hernández A, Espinosa C, Ruiz J (2010) Candidemias nosocomiales: nuevos retos de un problema emergente. Rev Esp Quimiter 23:158-168

30. FAO/WHO (2002) Guidelines for the evaluation of probiotics in food. Food and Agriculture Organization of the United Nations/World Health Organization, London, ON

31. Miller W, Munita J, Arias C (2014) Mechanisms of antibiotic resistance in enterococci. Expert Rev Anti-Infect Ther 12(10):1221-1236. https://doi.org/1 $0.1586 / 14787210.2014 .956092$

32. Danielsen M, Wind A (2003) Susceptibility of Lactobacillus spp. to antimicrobial agents. Int J Food Microbiol 82(1):1-11. https://doi.org/10.101 6/s0168-1605(02)00254-4

33. Abriouel H, Casado Muñoz M, Lerma L, Perez Montoro B, Bockelman W, Pichner R, Kabisch J, Cho G, Franz C, Gálvez A, Benomar N (2015) New insights in antibiotic resistance of Lactobacillus species from fermented foods. Food Res Int 78:465-481. https://doi.org/10.1016/j.foodres.2015.09.016

34. Pinto A, Barbosa J, Albano H, Isidro J, Teixeira P (2020) Screening of bacteriocinogenic lactic acid bacteria and their characterization as potential probiotics. Microorganisms 8(3). https://doi.org/10.3390/microorganisms803 0393

35. Magiorakos A, Srinivasan A, Carey R, Carmeli Y, Falagas M, Giske C, Harbarth S, Hindler J, Kahlmeter G, Olsson-Liljequist B, Paterson D, Rice L, Stelling J, Struelens M, Vatopoulos A, Weber J, Monnet D (2012) Multidrug-resistant, extensively drug-resistant and 86 pandrug-resistant bacteria: an international expert proposal for interim standard definitions for acquired resistance. Clin Microbiol Infect 18(3):268-281. https://doi.org/10.1111/j.14690691.2011.03570.x

36. Liu C, Zhang Z, Dong K, Yuan J, Guo X (2009) Antibiotic resistance of probiotic strains of lactic acid bacteria isolated from marketed foods and drugs. Biomed Environ Sci 22(5):401-412. https://doi.org/10.1016/S0895-3 988(10)60018-9

37. Cao Z, Pan H, Li S, Shi C, Wang S, Wang F, Ye P, Jia J, Ge C, Lin Q, Zhao Z (2019) In vitro evaluation of probiotic potential of lactic acid bacteria isolated from Yunnan De'ang pickled tea. Probiotics and Antimicro Prot 11(1):103-112. https://doi.org/10.1007/s12602-018-9395-x

38. Mendonça A, de Lucena B, de Morais M, de Morais M (2016) First identification of Tn916-like element in industrial strains of Lactobacillus vini that spread the tet-M resistance gene. FEMS Microbiol Lett 363(3). https:// doi.org/10.1093/femsle/fnv240

39. Hughes R, Magee E, Bingham S (2000) Protein degradation in the large intestine: relevance to colorectal cancer. Curr Issues Intest Microbiol 1(2):5158

40. Samedi L, Charles A (2019) Isolation and characterization of potential probiotic lactobacilli from leaves of food plants for possible additives in pellet feeding. Ann Agric Sci 64(1):55-62. https://doi.org/10.1016/j.aoas.2019. 05.004

41. Jiang M, Wen H, Gou G, Liu T, Lu X, Deng D (2018) Preliminary study to evaluate the effects of dietary bile acids on growth performance and lipid metabolism of juvenile genetically improved farmed tilapia (Oreochromis niloticus) fed plant ingredient-based diets. Aquac Nutr 24(4):1175-1183. https://doi.org/10.1111/anu.12656
42. Gómez A, Kociubinski G, Pérez P, Disalvo E, De Antoni G (2002) Effect of bile on the lipid composition and surface properties of bifidobacteria. J Appl Microbiol 93:794-799. https://doi.org/10.1046/j.1365-2672.2002.01747.x

43. Li M, Wang Y, Cui H, Li Y, Sun Y, Qiu H (2020) Characterization of lactic acid bacteria isolated from the gastrointestinal tract of a wild boar as potential probiotics. Front Vet Sci https://doi.org/10.3389/fvets.2020.00049

44. Abdulla A, Abed T, Saeed A (2014) Adhesion, autoaggregation and hydrophobicity of six Lactobacillus strains. Br Microbiol Res J 4(4):381-391. https://doi.org/10.9734/BMRJ/2014/6462

45. Hevia A, Martínez N, Ladero V, Álvarez M, Margolles A, Sánchez B (2013) An extracellular serine/threonine-rich protein from Lactobacillus plantarum NCIMB 8826 is a novel aggregation-promoting factor with affinity to mucin. Appl Environ Microbiol 79(19):6059-6066. https://doi.org/10.1128/AEM.01 657-13

46. Kos B, Suskovic J, Vukovic S, Simpraga M, Frece J, Matosic S (2003) Adhesion and aggregation ability of probiotic strain Lactobacillus acidophilus M92. J Appl Microbiol 94(6):981-987. https://doi.org/10.1046/j.1365-2672.2003.0191 $5 . x$

47. Al Seraih A, Belguesmia Y, Cudennec B, Baah J, Drider D (2018) In silico and experimental data claiming safety aspects and beneficial attributes of the bacteriocinogenic strain Enterococcus faecalis B3A-B3B. Probiotics and Antimicrob Prot 10(3):456-465. https://doi.org/10.1007/s12602-017-9357-8

48. Sharma K, Attri S, Goel G (2019) Selection and evaluation of probiotic and functional characteristics of autochthonous lactic acid bacteria isolated from fermented wheat flour dough babroo. Probiotics and Antimicro Prot 11(3): 774-784. https://doi.org/10.1007/s12602-018-9466-z

49. Dowdell P, Chankhamhaengdecha S, Panbangred W, Janvilisri T, Aroonnual A (2019) Probiotic activity of Enterococcus faecium and Lactococcus lactis isolated from Thai fermented sausages and their protective effect against Clostridium difficile. Probiotics and Antimicrob Prot 12(2):641-648. https:// doi.org/10.1007/s12602-019-09536-7

\section{Publisher's Note}

Springer Nature remains neutral with regard to jurisdictional claims in published maps and institutional affiliations.

\section{Submit your manuscript to a SpringerOpen ${ }^{\circ}$ journal and benefit from:}

- Convenient online submission

- Rigorous peer review

- Open access: articles freely available online

High visibility within the field

- Retaining the copyright to your article

Submit your next manuscript at $>$ springeropen.com 